\title{
Quantitative models of hydrothermal fluid-mineral reaction: The Ischia case
}

\author{
Rossella Di Napoli ${ }^{\mathrm{a}, *}$, Cinzia Federico ${ }^{\mathrm{b}}$, Alessandro Aiuppa ${ }^{\mathrm{a}, \mathrm{b}}$, \\ Massimo D'Antonio $^{\mathrm{c}, \mathrm{d}}$, Mariano Valenza ${ }^{\mathrm{a}}$ \\ a Dipartimento DiSTeM, Università di Palermo, Palermo, Italy \\ ${ }^{\mathrm{b}}$ Istituto Nazionale di Geofisica e Vulcanologia, sezione di Palermo, Palermo, Italy \\ ${ }^{\mathrm{c}}$ Dipartimento di Scienze della Terra, Università Federico II, Napoli, Italy \\ ${ }^{\mathrm{d}}$ Istituto Nazionale di Geofisica e Vulcanologia - Osservatorio Vesuviano, Napoli, Italy
}

Received 13 July 2012; accepted in revised form 28 November 2012; Available online 10 December 2012

\begin{abstract}
The intricate pathways of fluid-mineral reactions occurring underneath active hydrothermal systems are explored in this study by applying reaction path modelling to the Ischia case study. Ischia Island, in Southern Italy, hosts a well-developed and structurally complex hydrothermal system which, because of its heterogeneity in chemical and physical properties, is an ideal test sites for evaluating potentialities/limitations of quantitative geochemical models of hydrothermal reactions. We used the EQ3/6 software package, version 7.2b, to model reaction of infiltrating waters (mixtures of meteoric water and seawater in variable proportions) with Ischia's reservoir rocks (the Mount Epomeo Green Tuff units; MEGT). The mineral assemblage and composition of such MEGT units were initially characterised by ad hoc designed optical microscopy and electron microprobe analysis, showing that phenocrysts (dominantly alkali-feldspars and plagioclase) are set in a pervasively altered (with abundant clay minerals and zeolites) groundmass. Reaction of infiltrating waters with MEGT minerals was simulated over a range of realistic (for Ischia) temperatures $\left(95-260^{\circ} \mathrm{C}\right.$ ) and $\mathrm{CO}_{2}$ fugacities $\left(10^{-0.2}\right.$ to $10^{0.5}$ ) bar. During the model runs, a set of secondary minerals (selected based on independent information from alteration minerals' studies) was allowed to precipitate from model solutions, when saturation was achieved. The compositional evolution of model solutions obtained in the 95$260^{\circ} \mathrm{C}$ runs were finally compared with compositions of Ischia's thermal groundwaters, demonstrating an overall agreement. Our simulations, in particular, well reproduce the Mg-depleting maturation path of hydrothermal solutions, and have end-ofrun model solutions whose $\mathrm{Na}-\mathrm{K}-\mathrm{Mg}$ compositions well reflect attainment of full-equilibrium conditions at run temperature. High-temperature $\left(180-260^{\circ} \mathrm{C}\right)$ model runs are those best matching the $\mathrm{Na}-\mathrm{K}-\mathrm{Mg}$ compositions of Ischia's most chemically mature water samples, supporting quenching of deep-reservoir conditions for these surface manifestations; whilst $\mathrm{Fe}, \mathrm{SiO}_{2}$ and, to a lesser extent, $\mathrm{SO}_{4}$ contents of natural samples are better reproduced in low-temperature $\left(95^{\circ} \mathrm{C}\right)$ runs, suggesting that these species reflect conditions of water-rock interaction in the shallow hydrothermal environment. The ability of model runs to reproduce the compositional features of Ischia's thermal manifestations, demonstrated here, adds supplementary confidence on reaction path modelling as a realistic and insightful representation of mineral-fluid hydrothermal reactions. Our results, in particular, demonstrate the significant impact of host rock minerals' assemblage in governing the paths and trends of hydrothermal fluids' maturation.
\end{abstract}

(C) 2012 Elsevier Ltd. All rights reserved.

\section{INTRODUCTION}

* Corresponding author. Tel.: +39 09123861615; fax: +39 0916168376.

E-mail address: rossella.dinapoli@unipa.it (R. Di Napoli).
In unpolluted catchments, the chemistry of groundwaters is to a large extent controlled by water-rock interaction processes taking place between infiltrating superficial 
waters and host rock formations (Drever, 1997). The major element concentrations of groundwaters are, however, radically dissimilar from compositions of pristine (unaltered) aquifer rocks, reflecting the variable 'weatherability' of different primary minerals, and the formation of secondary solid phases during incongruent dissolution (Krauskopf and Bird, 1995; Berner and Berner, 1996; Stumm and Morgan, 1996; Langmuir, 1997).

From a thermodynamic viewpoint, geochemical processes involving groundwaters and reservoir rock minerals are far from equilibrium. However, rock weathering can conventionally be parceled into a sequence of partial equilibrium states, in which the system is out of equilibrium overall, but equilibrium conditions exist between dissolved aqueous species and some secondary minerals (Helgeson, 1968). In such a view, water-rock interactions are described by an array of mass transfer reactions from primary minerals to other phases in the system (e.g., the aqueous solution and secondary minerals) (Helgeson et al., 1969, 1970). By a combination of mass balance and equilibrium relations, the chemical evolution of aqueous solutions and mineral paragenesis over time can be tracked (Helgeson, 1968, 1979; Helgeson et al., 1969, 1970; Steinmann et al., 1994), and compared with natural groundwater compositions (taken to represent different steps of water maturation along a single evolutionary trend).

Even though initially developed to investigate waterrock interactions in shallow/surface (often sedimentary) environments (Helgeson, 1968, 1979; Helgeson et al., 1969; Gislason and Eugster, 1987), the Helgeson's approach of rock-solution mass transfer has also been applied to quantitative exploration of reaction dynamics in hydrothermal systems (e.g., Giggenbach, 1984). In such extreme environments, intense water-rock reactions are driven by prevailingly high temperatures and supply of magmatic/ hydrothermal dissolved gases, making infiltrating waters particularly aggressive relative to aquifer rocks (Reed, 1982; Giggenbach, 1988; Hedenquist and Lowenstern, 1994; Symonds et al., 2001). While a continuous supply of acidic gases may maintain the water-rock system at very immature (far-from-equilibrium) stages in the shallow hydrothermal envelop, full-equilibrium conditions are more likely to be reached in deep seated hydrothermal aquifers, because of far longer timescales of water residence (Giggenbach, 1984, 1988). Since kinetics of fluid-mineral reactions generally decrease with decreasing temperature, deep-equilibrated waters often preserve, upon their ascent toward the surface, their reservoir-derived compositions, which then become potentially valuable hydrothermal geo-indicators (Giggenbach, 1988).

This notwithstanding, reaction path modelling has been applied at active hydrothermal systems in a relatively limited number of occasions (Lonker et al., 1993; Gianelli and Grassi, 2001; Aiuppa et al., 2005; Gambardella et al., 2005; Hurwitz et al., 2007; Federico et al., 2008; Lelli et al., 2008; Stefánsson, 2010; Gysi and Stefánsson, 2011, 2012; Markússon and Stefánsson, 2011; Stefánsson et al., 2011; Tempel et al., 2011). This may reflect the inherent difficulties in playing with the variety of simultaneously occurring mineral-solution reactions, the complex and time/ space-variable paragenesis of secondary minerals, and the large $P-T$-redox gradients over relatively small areas, which are all characteristic of hydrothermal systems.

In this paper, we attempt at applying the principles and methods of reaction path modeling to quantitatively investigate water-rock interaction processes at Ischia's hydrothermal system. Ischia, a small active volcanic island in the Gulf of Naples (Southern Italy), is known to host a structurally complex hydrothermal system, characterized by several superposed and interconnected thermal reservoirs, recharged by infiltrated meteoric water and seawater (De Gennaro et al., 1984; Panichi et al., 1992; Caliro et al., 1999; Inguaggiato et al., 2000; Aiuppa et al., 2006; Morell et al., 2008; Di Napoli et al., 2009, 2011). Because of this complex hydrothermal setting, and in light of the compositional variety of surface thermal manifestations, Ischia is a particularly suitable site to test the potentialities of reaction path modeling in characterizing hydrothermal mineralfluid reactions. We show below that our model results satisfactorily reproduce the chemical compositions of thermal fluids, a hint for the significant contribution reaction path modeling can offer in unrevealing the key processes occurring at volcano-hosted hydrothermal systems.

\section{THE STUDY AREA}

Ischia, a volcanic field characterized by a resurgent caldera (Orsi et al., 1991), has been the site of recurrent volcanism over the past $150 \mathrm{ka}$, and most recently on $1302 \mathrm{AD}$ (Arso eruption) (Vezzoli, 1988; Civetta et al., 1991; Orsi et al., 1996, 2003). Volcanic rocks on the island have been deposited by both effusive and highly to moderately explosive eruptions. The largest-scale volcanic event is the caldera-forming Mount Epomeo Green Tuff eruption (MEGT) dated at $~ 55$ kyr BP (Vezzoli, 1988), during which thick (>270 m; Brown et al., 2008) green-coloured ignimbrite deposits of trachitic to phonolitic composition were erupted (Civetta et al., 1991; Orsi et al., 1991; Brown et al., 2008). The subsidence resulting from the MEGT caldera collapse led to flooding of most of the present island by the sea, and to intense submarine alteration of MEGT deposits. Marine terrigenous formations topping the MEGT indicate that a 70-120 m deep basin formed in the central part of the island (Barra et al., 1992). A resurgence phenomenon, started not before $33 \mathrm{kyr}$ BP, caused uplift of the central portion of the island and formation of the Mount Epomeo resurgent block (Orsi et al., 1991). This resurgence is thought to have played a structural control on eruption dynamics during the last $(<10 \mathrm{Ka}$ ) eruptive cycle (Orsi et al., 1991).

Ischia volcano is presently undertaking a period of quiescence, with intense seismicity, hot water discharges, fumarolic emissions and diffuse soil degassing. The presence of a large hydrothermal system at Ischia was firstly demonstrated in the late $30 \mathrm{~s}$, during a project of exploitation of thermal resources in the southern sector of the island. Results of explorative drillings (Ippolito, 1942; Penta, 1949, 1954; Penta and Conforto, 1951a,b) and for compositions of thermal water discharges and fumarolic emissions (Carapezza et al., 1988; Panichi et al., 1992; Tedesco, 1996; Caliro 
et al., 1999; Inguaggiato et al., 2000; Chiodini et al., 2004; Aiuppa et al., 2006) were recently synthesised in a model of hydrothermal fluid circulation (Di Napoli et al., 2009, 2011), in which a shallow thermal aquifer, recharged by infiltrating meteoric and marine waters, is thought to be heated by fluids rising from two distinct deep hydrothermal reservoirs, having equilibrium temperatures of $\sim 150$ $200{ }^{\circ} \mathrm{C}$ and $\sim 260^{\circ} \mathrm{C}$, respectively. Heat sustaining hydrothermal circulation is overall provided by a deep magma storage zone (Moretti et al., 2011), which degassing provides a persistent volatile flux (Carapezza et al., 1988; Tedesco, 1996; Inguaggiato et al., 2000; Chiodini et al., 2004; Di Napoli et al., 2009).

\section{MATERIALS AND METHODS}

Our models here make use of pre-existing (thermal waters) and ad hoc obtained (minerals) information on compositions of a variety of Ischia's geological materials. This section briefly summaries the analytical methods used.

\subsection{Thermal waters}

The water chemistry data we make use of in this manuscript are taken from Di Napoli et al. (2009). We extracted the subset of thermal $\left(>25^{\circ} \mathrm{C}\right)$ waters (109 samples) from the original compilation. These data were obtained using traditional analytical techniques in geothermal exploration (e.g., ion chromatography for major dissolved ions, with analytical accuracy better then $\pm 3 \%$; spectrophotometry for $\mathrm{Si}$ and ICP-MS for $\mathrm{Fe}$ ). The reader is referred to the original Di Napoli et al. (2009) manuscript for details on analytical procedures and uncertainties.

\subsection{Rock samples}

Modal and mineral chemistry data were obtained on a representative sample (MEGT0322) of the Mount Epomeo Green Tuff deposit. The modal abundances of the main and

Table 1

Modal composition of MEGT0322 sample.

\begin{tabular}{lr}
\hline Mineral & vol. \% \\
\hline Phenocrysts & \\
Alkali-feldspar & 20 \\
Plagioclase & 7 \\
Clinopyroxene & 5 \\
Black mica & 3 \\
Opaque oxide & 1 \\
Groundmass & \\
Alkali-feldspar & 9 \\
Black mica & 2 \\
Opaque oxide & 1 \\
Zeolites & 20 \\
Clay minerals & 21 \\
Fe oxyhydroxides & 6 \\
Vesicles & 5 \\
Sum & 100 \\
\hline
\end{tabular}

Gypsum is estimated at 0.04 vol.\% based on bulk-rock S content of $\sim 100 \mathrm{mg} / \mathrm{kg}$ (Fowler et al., 2007). accessory minerals in MEGT0322 were first evaluated by optical microscopy (Table 1). Then, mineral chemistry data were obtained by electron microprobe analysis (EMPA) at the HP-HT Laboratory of Experimental Volcanology and Geophysics of Istituto Nazionale di Geofisica e Vulcanologia, Sezione di Roma, Italy. Data are reported in Table 2. EMPA measurements were performed using a Jeol JXA 8200 Superprobe, equipped with five wavelength dispersive spectrometers, and an energy dispersive spectrometer. Operating conditions were $15 \mathrm{kV}$ accelerating voltage and $7 \mathrm{nA}$ probe current. A probe diameter of $5 \mu \mathrm{m}$, with a final spot size of about $7 \mu \mathrm{m}$, was used to reduce alkali loss. Counting time was $10 \mathrm{~s}$ on peak and $5 \mathrm{~s}$ on background, and data reduction was carried out using a ZAF correction method.

\section{GEOCHEMICAL AND MINERALOGICAL CONSTRAINTS}

In a forward model approach as that undertaken here, a complete a priori knowledge of the mineral-fluid system is an essential pre-requisite for quantitative exploration of hydrothermal reactions. Correct initialisation of reaction path models, in particular, requires knowledge of the environment ( $P, T$, recharge water salinity and chemistry) of water-rock interactions and the mineral assemblage and composition of dissolving host rocks. We review below the constraints we can set, based on existing knowledge, to confine our computations to a set of conditions pertinent to the Ischia's system.

\subsection{Structure of the hydrothermal system, and environments of water-rock interaction}

In spite of its limited extension $\left(\sim 46 \mathrm{~km}^{2}\right)$, Ischia is characterised by significant heterogeneity in the physical-chemical features of superficial hydrothermal manifestations, a hint for a complex subsurface hydrothermal circulation. We build on previous work on Ischia (Di Napoli et al., 2009 , 2011) to schematically image the structure of the Ischia hydrothermal system (Fig. 1). This sketch contains the geological-geochemical constraints used to initialise our hydrothermal reaction models described below (cf. Section 5).

Fig. 1 identifies a shallow (depth, about $100 \mathrm{~m}$ b.s.1.) aquifer, likely hosted within the MEGT formation (Celico et al., 1999; Di Napoli et al., 2011), tapped by drillings in almost all sectors of Ischia. Groundwaters circulating in the shallow aquifer have temperatures up to boiling, and range in composition from diluted bicarbonate waters to more saline and Cl-rich waters; this fact has been taken as an evidence of dual (meteoric plus seawater) recharge to the aquifer (Panichi et al., 1992; Inguaggiato et al., 2000; Aiuppa et al., 2006; Di Napoli et al., 2009).

The high $\mathrm{K} / \mathrm{Na}$ ratios and strong $\mathrm{Mg}$-depletion $(\mathrm{Mg}$ concentrations to as low as $0.1 \mathrm{mg} / \mathrm{l}$ ) of numerous groundwater samples suggest, however, that the shallow aquifer is additionally fed (apart from superficial recharge) by hotter and chemically more mature waters rising from deep hydrothermal reservoirs (Panichi et al., 1992; Inguaggiato et al., 
Table 2

Representative EMP analyses of minerals from sample MEGT0322.

\begin{tabular}{|c|c|c|c|c|c|c|c|c|c|c|c|c|c|}
\hline $\begin{array}{l}\text { Mineral } \\
\text { Spot label } \\
\text { Type } \\
\end{array}$ & $\begin{array}{l}\text { Plagioclase } \\
\text { c5fd1r } \\
\text { m-ph rim }\end{array}$ & $\begin{array}{l}\text { Plagioclase } \\
\text { c4fdlr } \\
\text { ph rim }\end{array}$ & $\begin{array}{l}\text { Alkali- } \\
\text { feldspar } \\
\text { c } 4 \text { fd } 2 r \\
\text { ph rim }\end{array}$ & $\begin{array}{l}\text { Alkali- } \\
\text { feldspar } \\
\text { clfdl } \\
\text { ph rim }\end{array}$ & $\begin{array}{l}\text { Alkali- } \\
\text { feldspar } \\
\text { c5bfd1r } \\
\text { ph rim }\end{array}$ & $\begin{array}{l}\text { Alkali- } \\
\text { feldspar } \\
\text { c5_z2 } \\
\text { m-lt }\end{array}$ & $\begin{array}{l}\text { Alkali- } \\
\text { feldspar } \\
\text { c5_z1 } \\
\text { m-lt }\end{array}$ & $\begin{array}{l}\text { Clino- } \\
\text { pyroxene } \\
\text { c2_px1c } \\
\text { m-ph core }\end{array}$ & $\begin{array}{l}\text { Clino- } \\
\text { pyroxene } \\
\text { c2_px1r } \\
\text { m-ph rim }\end{array}$ & $\begin{array}{l}\text { Clino- } \\
\text { pyroxene } \\
\text { c4px1c } \\
\text { ph core }\end{array}$ & $\begin{array}{l}\text { Clino- } \\
\text { pyroxene } \\
\text { c5px } 1 \\
\text { m-ph core }\end{array}$ & $\begin{array}{l}\text { Opaque } \\
\text { oxide } \\
\text { c6_ox } \\
\text { m-lt }\end{array}$ & $\begin{array}{l}\text { Black mica } \\
\text { c2_bt2 } \\
\text { ph core }\end{array}$ \\
\hline $\mathrm{SiO}_{2}$ & 57.00 & 60.14 & 64.92 & 65.47 & 65.18 & 65.79 & 65.38 & 47.06 & 51.35 & 51.59 & 51.65 & 0.07 & 37.54 \\
\hline $\mathrm{TiO}_{2}$ & 0.06 & 0.04 & 0.04 & 0.08 & 0.06 & 0.13 & 0.29 & 0.95 & 0.65 & 0.61 & 0.58 & 7.41 & 5.57 \\
\hline $\mathrm{Al}_{2} \mathrm{O}_{3}$ & 25.81 & 24.20 & 19.07 & 18.59 & 18.55 & 18.38 & 18.11 & 6.71 & 3.90 & 2.71 & 1.80 & 2.81 & 14.10 \\
\hline $\mathrm{FeO}_{\text {TOт }}$ & 0.52 & 0.40 & 0.29 & 0.18 & 0.24 & 0.19 & 0.31 & 7.98 & 4.56 & 7.81 & 8.53 & 80.06 & 13.84 \\
\hline $\mathrm{MnO}$ & b.d.l. & b.d.1. & b.d.l. & b.d.l. & b.d.l. & b.d.l. & b.d.1. & 0.16 & 0.08 & 0.44 & 0.77 & 0.96 & 0.31 \\
\hline $\mathrm{MgO}$ & 0.07 & 0.02 & b.d.1. & b.d.l. & 0.02 & 0.04 & 0.03 & 12.41 & 15.83 & 14.09 & 13.11 & 2.13 & 15.49 \\
\hline $\mathrm{CaO}$ & 8.94 & 6.40 & 1.05 & 0.63 & 0.59 & 0.24 & 0.47 & 23.34 & 23.51 & 22.74 & 23.04 & 0.10 & 0.03 \\
\hline $\mathrm{Na}_{2} \mathrm{O}$ & 5.41 & 6.63 & 4.30 & 2.86 & 2.79 & 6.43 & 7.27 & 0.48 & 0.13 & 0.59 & 0.64 & & 0.59 \\
\hline $\mathrm{K}_{2} \mathrm{O}$ & 1.32 & 1.78 & 9.97 & 12.58 & 12.68 & 7.60 & 5.64 & b.d.l. & b.d.l. & b.d.l. & b.d.l. & & 10.08 \\
\hline $\mathrm{SrO}$ & 0.11 & 0.04 & 0.04 & 0.14 & 0.15 & b.d.1. & b.d.l. & n.a. & n.a. & n.a. & n.a. & & \\
\hline $\mathrm{BaO}$ & 0.01 & b.d.1. & b.d.l. & 0.07 & 0.27 & b.d.1. & 0.02 & n.a. & n.a. & n.a. & n.a. & & 0.22 \\
\hline $\mathrm{Cl}$ & & & & & & & & & & & & & 0.05 \\
\hline $\mathrm{F}$ & & & & & & & & & & & & & 0.58 \\
\hline Sum & 99.25 & 99.65 & 99.67 & 100.59 & 100.53 & 98.80 & 97.52 & 99.09 & 99.99 & 100.57 & 100.11 & 93.55 & 98.39 \\
\hline $\mathrm{Fe}_{2} \mathrm{O}_{3}$ & & & & & & & & 5.86 & 1.76 & 3.34 & 3.19 & 51.5 & \\
\hline $\mathrm{FeO}$ & & & & & & & & 2.71 & 2.97 & 4.80 & 5.66 & 33.7 & \\
\hline Sum & & & & & & & & 99.69 & 100.18 & 100.90 & 100.45 & 98.7 & \\
\hline \multicolumn{14}{|c|}{$\begin{array}{l}\text { Cations per } \\
\text { formula unit }\end{array}$} \\
\hline $\mathrm{Si}$ & 10.352 & 10.806 & 11.828 & 11.922 & 11.905 & 11.968 & 11.968 & 1.760 & 1.878 & 1.899 & 1.923 & & 2.745 \\
\hline $\mathrm{Ti}$ & 0.008 & 0.006 & 0.006 & 0.011 & 0.008 & 0.018 & 0.040 & 0.240 & 0.122 & 0.101 & 0.077 & & 0.306 \\
\hline $\mathrm{Al}^{\mathrm{IV}}$ & & & & & & & & 0.056 & 0.046 & 0.017 & 0.001 & & 1.215 \\
\hline $\mathrm{Al}^{\mathrm{VI}}$ & & & & & & & & 1.760 & 1.878 & 1.899 & 1.923 & & 0.000 \\
\hline Al tot & 5.524 & 5.125 & 4.094 & 3.990 & 3.993 & 3.941 & 3.907 & & & & & & \\
\hline $\mathrm{Fe}^{3+}$ & 0.079 & 0.060 & 0.044 & 0.028 & 0.037 & 0.029 & 0.048 & 0.165 & 0.049 & 0.093 & 0.089 & & 0.760 \\
\hline $\mathrm{Fe}^{2+}$ & & & & & & & & 0.085 & 0.091 & 0.148 & 0.176 & & 0.467 \\
\hline $\mathrm{Mn}$ & & & & & & & & 0.005 & 0.002 & 0.014 & 0.024 & & 0.019 \\
\hline $\mathrm{Mg}$ & 0.019 & 0.005 & & & 0.006 & 0.011 & 0.008 & 0.692 & 0.864 & 0.773 & 0.728 & & 1.688 \\
\hline $\mathrm{Ca}$ & 1.739 & 1.231 & 0.204 & 0.123 & 0.116 & 0.047 & 0.093 & 0.935 & 0.921 & 0.897 & 0.919 & & 0.002 \\
\hline $\mathrm{Na}$ & 1.904 & 2.309 & 1.519 & 1.008 & 0.989 & 2.269 & 2.580 & 0.035 & 0.009 & 0.042 & 0.046 & & 0.084 \\
\hline $\mathrm{K}$ & 0.306 & 0.408 & 2.318 & 2.923 & 2.954 & 1.763 & 1.318 & & & & & & 0.940 \\
\hline $\mathrm{Sr}$ & 0.012 & 0.004 & 0.004 & 0.014 & 0.016 & 0.000 & 0.000 & & & & & & \\
\hline $\mathrm{Ba}$ & 0.001 & 0.000 & 0.000 & 0.005 & 0.019 & 0.000 & 0.001 & & & & & & 0.006 \\
\hline $\mathrm{F}$ & & & & & & & & & & & & & 0.134 \\
\hline $\mathrm{Cl}$ & & & & & & & & & & & & & 0.006 \\
\hline $\mathrm{OH}$ & & & & & & & & & & & & & 1.860 \\
\hline Sum & 19.944 & 19.954 & 20.016 & 20.024 & 20.043 & 20.045 & 19.963 & 4.000 & 4.000 & 4.000 & 4.000 & & 10.232 \\
\hline An $m o l \%$ & 43.89 & 31.15 & 5.04 & 3.01 & 2.83 & 1.16 & 2.33 & & & & & & \\
\hline
\end{tabular}




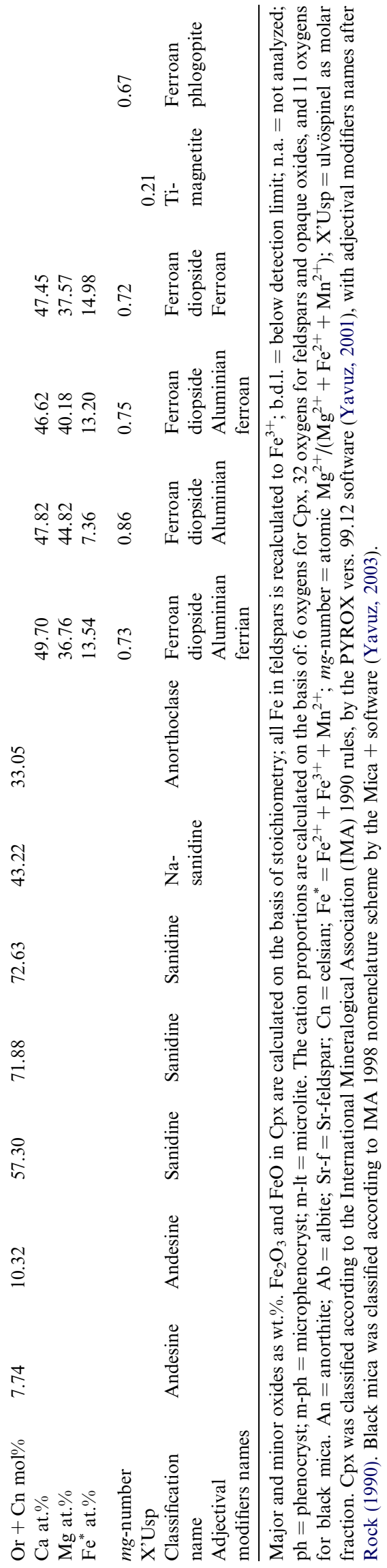

2000; Aiuppa et al., 2006; Di Napoli et al., 2009, 2011). These fluids fall indeed in the field of partially equilibrated waters in the commonly used Giggenbach's (1988) Na-K$\mathrm{Mg}$ triangular diagram (examples of which are given in Fig. 9), and are therefore likely to have long interacted (and equilibrated) with rocks at reservoir conditions. The nature ( $P-T$ conditions) of these deep hydrothermal reservoirs at Ischia have been inferred via geothermometric studies on surface manifestations (Panichi et al., 1992; Inguaggiato et al., 2000; Chiodini et al., 2004; Di Napoli et al., 2009) and explorative drillings (Ippolito, 1942; Penta, 1949, 1954; Penta and Conforto, 1951a,b). These studies concur to support the existence of at least two superposed hydrothermal reservoirs, probably both hosted within the MEGT series. The shallowest (150-300 $\mathrm{m}$ of depth) of the two reservoirs, clearly identified in the SW-sector of the island (Di Napoli et al., 2009), has inferred equilibrium temperatures of $150-200{ }^{\circ} \mathrm{C}$ (Fig. 1), and is thought to be mainly recharged by meteoric water-seawater mixtures: Di Napoli et al. (2009) identified two distinct types of thermal fluids (the Serrara and Citara thermal end-members; essentially differing for their salinity) being the surface discharges of this 150-300 m deep reservoir. The deepest reservoir is supposed to lie at about $1000 \mathrm{~m}$ (or more) of depth b.s.l., and has clear surface expression only on the northern portion of the island; a hot $\left(\sim 260^{\circ} \mathrm{C}\right)$, low-salinity and $\mathrm{HCO}_{3}$-rich fluid (the so-called Casamicciola thermal endmember; Di Napoli et al., 2009), indicative of a prevalent meteoric recharge, circulates in this reservoir.

There is clear chemical and isotopic evidence (Carapezza et al., 1988; Tedesco, 1996; Inguaggiato et al., 2000; Chiodini et al., 2004; Di Napoli et al., 2009) for that the Ischia's thermal reservoirs, described above, are supplied by magma-derived volatiles, likely sourced by a degassing and cooling magmatic body at depth (Moretti et al., 2011). This ultimately sustains fluids circulation.

\subsection{Rock and mineral chemistry}

At Ischia Island, there is a general consensus on that hydrothermal circulation takes place mostly within thick intra-caldera ignimbrite deposits produced by the MEGT eruption (Sbrana et al., 2009, 2010). The MEGT pyroclastic sequence (recently studied in detail by Brown et al., 2008) includes pumice falls, non-welded to weakly welded ignimbrites, and lithic breccia deposits. The juvenile portion of the MEGT is made up of pumices, and dense glassy clasts in breccia. Whole-rock composition of MEGT juvenile portion varies up-section from trachytic to phonolitic (Brown et al., 2008, and INGV-Osservatorio Vesuviano, unpublished data), a recurrent compositional range over the entire Ischia volcanic history (e.g., Vezzoli, 1988; Civetta et al., 1991; D'Antonio et al., 2007). The characteristic green colour of the MEGT has been attributed to post-emplacement alteration, due to prolonged chemical exchange with fluids of marine origin (Vezzoli, 1988; Sbrana et al., 2009, 2010) after the caldera collapse.

The MEGT0322 sample, which according to previous work (Brown et al., 2008 and INGV-Osservatorio Vesuviano, unpublished data) well averages the 


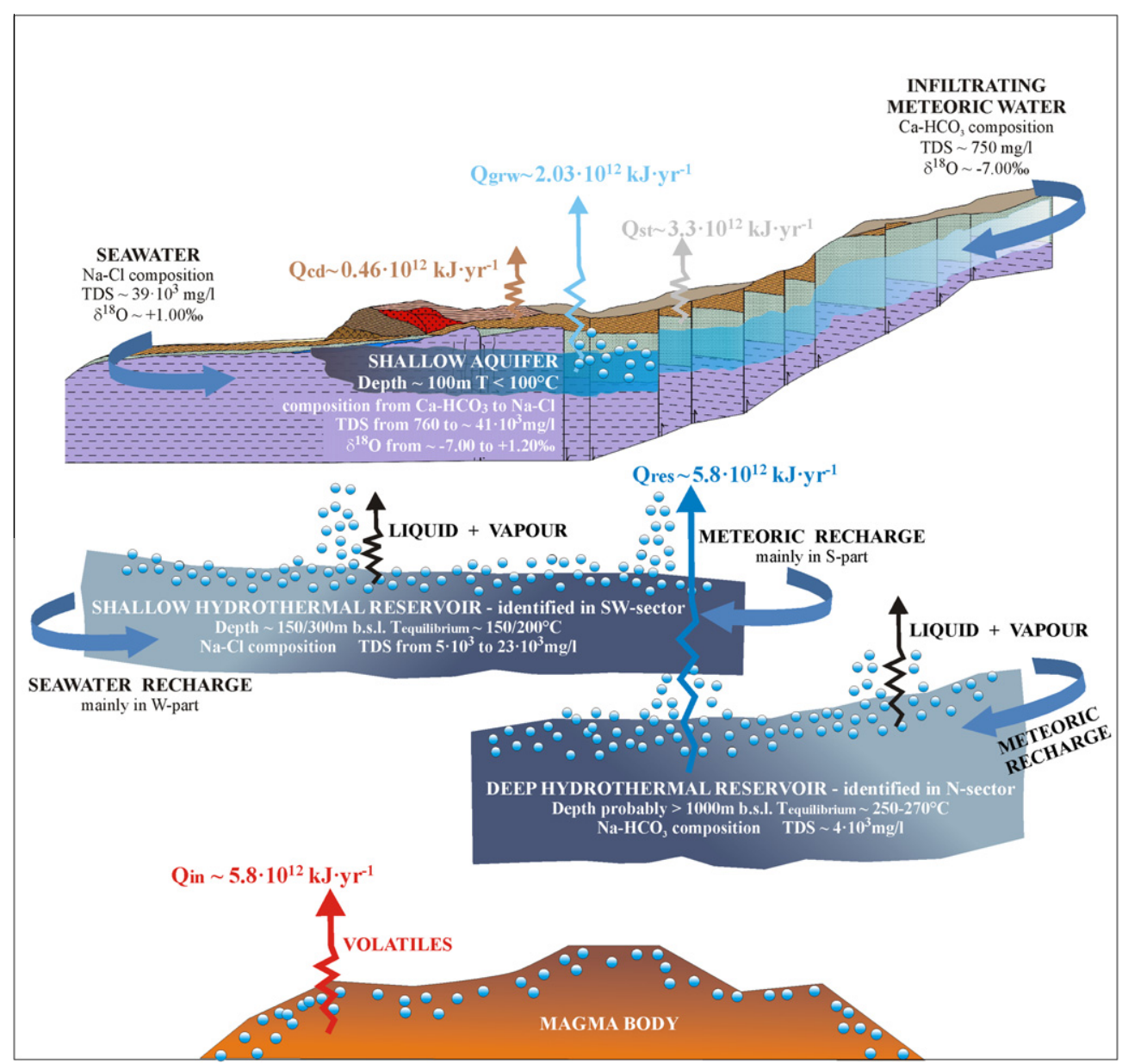

Fig. 1. Geochemical conceptual model of the chemical-physical structure of Ischia's hydrothermal system. Depth, temperature and chemical composition data for Ischia's reservoirs are taken from Di Napoli et al. (2009, 2011). The main outcomes of thermal budget proposed by Di Napoli et al. (2009) are also indicated. Degassing of a cooling magmatic body at depth sustains the activity of the Ischia's hydrothermal system, providing heat $Q_{\text {in }}$ (transferred by a volatiles flux) to the deep and shallow hydrothermal reservoirs. In a steady state, the same heat amount is supplied to the shallow aquifer from the beneath hydrothermal reservoirs $\left(Q_{\text {res }}=Q_{\text {in }}\right)$ by rising liquid and vapour phases. This amount of heat is (i) dissipated by the shallow groundwater system to warm the shallow infiltrating waters (meteoric and seawater) up to the boiling temperature $\left(Q_{\mathrm{grw}}\right)$, (ii) lost by conduction to the overlying rocks $\left(Q_{\mathrm{cd}}\right)$, and finally (iii) spent by steam transport and condensation in the very shallow levels of soil in active fumarolic fields $\left(Q_{\mathrm{st}}\right)$.

mineralogical-chemical features of the MEGT deposit, was selected in this study as representative of the primary rock materials thermal waters interact with at Ischia. The sample was collected from a matrix-rich, non-welded ignimbrite deposit, cropping out in intra-caldera position. Highly porphyritic ( $\sim 36$ vol. $\%)$ poorly vesicular ( $\sim 5$ vol. $\%$; likely as an effect of vesicle sealing due to secondary mineral deposition) juvenile pumice fragments are abundant ( $\sim 75$ vol. $\%)$ over the deposit.

MEGT0322 has a primary mineral assemblage (Table 1) including phenocrysts of alkali-feldspar ( 20 vol. $\%)$, plagioclase $(\sim 7$ vol. $\%)$, clinopyroxene ( $\sim 5$ vol. $\%)$, black mica $(\sim 3 \mathrm{vol} . \%)$ and opaque oxides ( $\sim 1$ vol. $\%)$. The phenocrysts, occurring both as single individuals and glomerocrysts, are set in a felty, glass-rich groundmass, where the original glass shards have been almost completely replaced by abundant clay minerals and zeolites in approximately similar amounts (35\% of groundmass), minor amounts of Fe-oxyhydroxides (10 vol. $\%$ of groundmass) and very low amounts of gypsum ( $<<1$ vol.\% of groundmass) (Table 1$)$. Sparse microlites of mostly alkali-feldspar ( $\sim 15$ vol. $\%$ of groundmass), minor black mica ( $\sim 3 \mathrm{vol} . \%$ of groundmass) and opaque oxide ( $\sim 2$ vol. $\%$ of groundmass), are also present (Table 1). An additional petrographic evidence of pervasive rock alteration is the common occurrence of optically distinct alkali-feldspar overgrowths around alkali-feldspar phenocrysts (coronae; see later).

Results of EMPA analyses on MEGT0322 minerals (Table 2) indicate that:

(i) Alkali-feldspars occur as the most abundant, sometimes rounded, phenocrysts in the analyzed rock. They spread over the compositional field of sanidine (from $\mathrm{Or}_{73} \mathrm{Ab}_{25}$ to $\mathrm{Or}_{57} \mathrm{Ab}_{38}$ ), although single phenocrysts are poorly zoned (Fig. 2a).

(ii) Plagioclase varies in the field of andesine $\left(\mathrm{An}_{44-31}\right.$ $\mathrm{Ab}_{48-59}$; see Fig. 2a) and shows a slight chemical normal zoning. There are recurrent K-rich coronae of 
alkali-feldspar which, given the evolved chemical character of the host whole-rock (trachytic) and of the coexisting Na-rich plagioclase, are thought to be secondary (=adularia), due to Na-loss under hydrothermal conditions, as observed in deep-seated volcanic rocks (e.g., D'Antonio and Kristensen, 2005).

(iii) Following the IMA 1990 pyroxene nomenclature scheme (Yavuz, 2001, and references therein), all analyzed clinopyroxenes (cpx) are ferroan diopside. In terms of relative enstatite and ferrosilite contents, they are slightly variable from $\mathrm{En}_{45} \mathrm{Fs}_{7}$ to $\mathrm{En}_{38} \mathrm{Fs}_{15}$; $\mathrm{Mg \#} \mathrm{(atomic} 100 * \mathrm{Mg} / \mathrm{Mg}+\mathrm{Fe}_{\text {tot }}+\mathrm{Mn}$ ), in the range 86-72 (Fig. 2b). The wollastonite content slightly decreases from 50 to 47 with increasing Fs contents (a possible effect of alteration), differently from the "usual" clinopyroxenes of alkaline affinity (Carbonin et al., 1984). The most primitive cpx, with a composition approaching that of diopside $(\mathrm{Mg} \#=86)$, has been found as the rim of a reversely zoned phenocryst. From the data above, we derive the following characteristic composition of the MEGT0322 ferroan diopside: $\mathrm{Ca}_{0.9} \mathrm{Mg}_{0.8} \mathrm{Fe}_{0.3} \mathrm{Si}_{2} \mathrm{O}_{6}$.

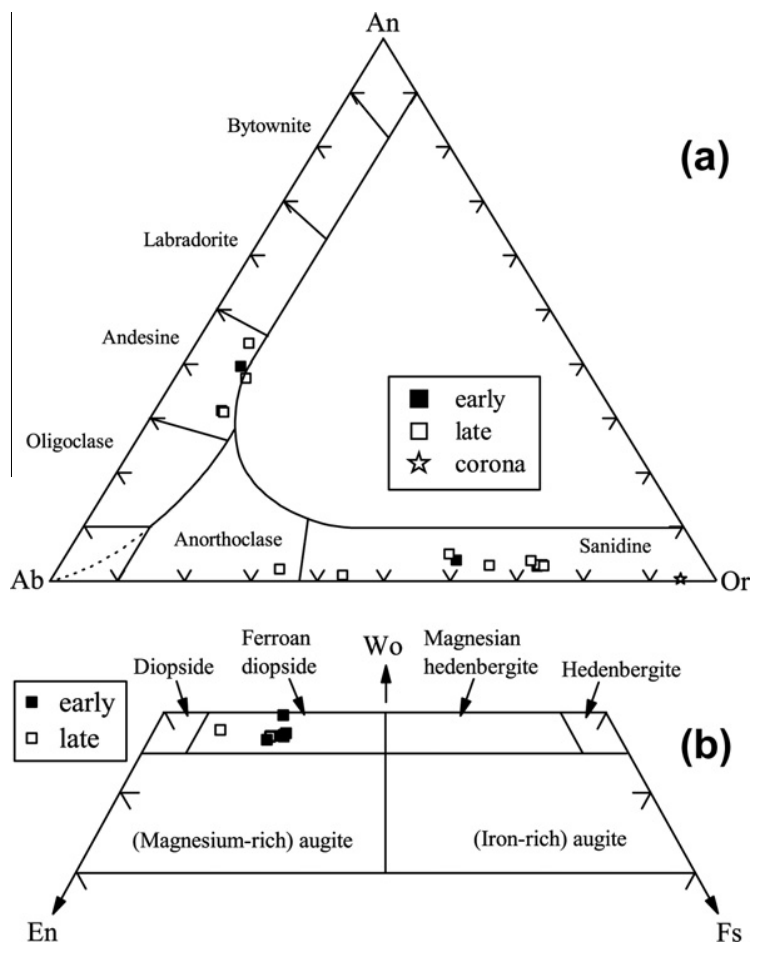

Fig. 2. (a) Ternary classification diagram $\mathrm{Ab}-\mathrm{An}-\mathrm{Or}$ for feldspars (Deer et al., 1992) showing all analyzed plagioclase and alkalifeldspar crystals from sample MEGT0322. Ab=albite; $\mathrm{An}=$ anorthite; $\quad$ Or $=$ orthoclase $\quad$ Early $=$ phenocryst $\quad$ cores; late $=$ phenocryst rims, microphenocrysts and microlites. (b) Portion of the pyroxene quadrilateral classification diagram DiHd-En-Fs (Rock, 1990) showing all analyzed clinopyroxene crystals from sample MEGT0322. Wo = wollastonite; En = enstatite; $F s=$ ferrosilite. Early $=$ phenocryst cores; late $=$ phenocryst rims, microphenocrysts and microlites. (iv) According to the IMA 1998 nomenclature scheme (Yavuz, 2003, and references therein), the common black mica, which occurs in the analyzed sample, is a ferrian phlogopite (corresponding to Mg-biotite, a disapproved IMA name). Its composition is quite homogeneous, with $\mathrm{Mg \#}$ (atomic $\mathrm{Mg} / \mathrm{Mg}+\mathrm{Fe}_{\text {tot }}$ ) around 0.67 .

(v) Ti-magnetite is the only opaque oxide occurring as micro-phenocrysts in the analyzed MEGT sample. Its ulvöspinel content (calculated according to Stormer, 1983) is around $23-24 \%$.

\section{QUANTITATIVE MODELLING OF HYDROTHERMAL REACTIONS}

We use reaction path modeling in the attempt to quantitatively constrain the chemical evolution of the fluid-mineral system upon water-rock hydrothermal interaction. Our target is to simulate the mass exchanges occurring between infiltrating recharge water (starting solution) and irreversibly dissolving rock-forming minerals at different stages of the water-rock interaction process, and at different $T$ and $P$ conditions (at the hydrothermal reservoirs conditions shown in Fig. 1); and to compare model results with natural samples (alteration mineral assemblage and thermal waters). Computations are performed throughout via the EQ3/6 code (version 7.2b; Wolery and Daveler, 1992) (see Appendix A for details on model theory).

\subsection{Initialization of model runs}

Application of reaction path modelling to a given case study requires a number of external constraints to be used, in order to confine calculations to a number of close-to-real solutions. Modelling of water-rock hydrothermal reactions requires exploring the wide range of $P-T-X$ conditions generally encountered in these highly dynamic systems. In this application, we initially run a set of reaction path simulations at $95^{\circ} \mathrm{C}$, which target was to quantitatively characterise water-rock reactions at conditions relevant to the Ischia's shallow groundwater system (Fig. 1). In a second stage, we extended our calculations to conditions relevant to deeper and hotter Ischia hydrothermal reservoirs (Fig. 1), by imposing temperatures of $180^{\circ} \mathrm{C}$ (an average of $T$ estimates for the intermediate reservoir of Fig. 1) and $260{ }^{\circ} \mathrm{C}$ (deep reservoir conditions; Fig. 1) in our isothermal model runs.

In view of the relative slow circulation (Celico et al., 1999) of groundwaters inside Ischia reservoir(s), our reaction path simulations were carried out in closed system mode, whereby solid reactants and secondary minerals are assumed to remain in contact with hydrothermal solutions during the entire process. We yet imposed the system to be open to a $\mathrm{CO}_{2}$-dominated gas phase, to satisfy the evidence of persistent supply of external (deep-rising) $\mathrm{CO}_{2}$ to Ischia's hydrothermal reservoirs (Moretti et al., 2011). Conceptually, this corresponds to simulating the interaction of hydrothermal solutions with a large (infinite) external $\mathrm{CO}_{2}$ reservoir, which acts as to buffer $\mathrm{CO}_{2}$ fugacity. 

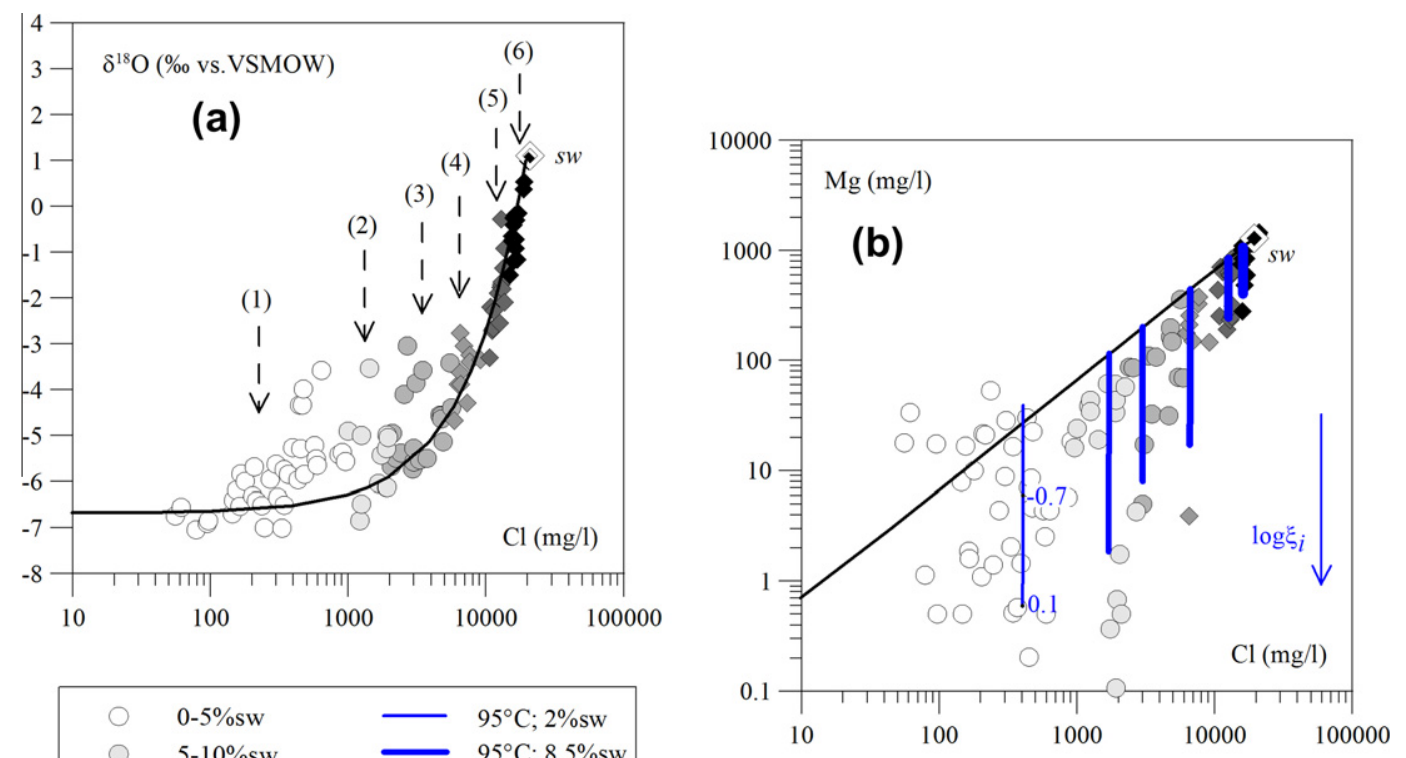

Fig. 3. Scatter plots for (a) $\delta^{18} \mathrm{O}$ vs. $\mathrm{Cl}$ and (b) $\mathrm{Mg}$ vs. $\mathrm{Cl}$ for Ischia's thermal groundwaters (data from Di Napoli et al., 2009). The diagrams confirm that Ischia groundwaters can be interpreted as mixtures (in various proportion) of meteoric water and seawater (sw) (the mixing curve is shown as a solid black curve). In the diagrams, Ischia water samples are clustered into 6 main groups, each characterized by a relatively narrow range of $\mathrm{Cl}$ concentrations, and therefore similar seawater mixing contributions (\%sw; see legend). Solid blue lines in (b) show the model ( $\xi$-dependent) evolution of solutions obtained in 6 different reaction-path model runs (all at $95^{\circ} \mathrm{C}$ ). Each simulation uses, as initial solution, a different meteoric water-seawater mixtures $(2,8.5,15,33,63$ and $80 \%$ sw; Table 3$)$, each pertinent to one of the above natural sample clusters. The extent of model reaction advancement is exemplified by the specific values of the reaction progress, reported along the $95^{\circ} \mathrm{C}-2 \%$ sw model curve (numbers as $\log \xi_{i}$ ).

Simulations at $95^{\circ} \mathrm{C}$ were carried out at fixed (constant) $\mathrm{CO}_{2}$ fugacity of $10^{-0.2}$ bar, which is representative of shallow reservoir conditions (Di Napoli et al., 2009). Although no direct information of $\mathrm{CO}_{2}$ fugacity at deep reservoir(s) condition is currently available, we can make an independent guess by assuming attainment of full-equilibrium conditions (water-gas-rock system) in the deep Ischia hydrothermal reservoirs. In such an assumption, at any given temperature, $\mathrm{CO}_{2}$ fugacity is fixed by the reaction involving (Giggenbach, 1984, 1988):

$\mathrm{Ca}$-Al-silicate $+\mathrm{K}$-feldspar $+\mathrm{CO}_{2}$

$$
\leftrightarrow \text { calcite }+\mathrm{K} \text {-mica }+4 \mathrm{SiO}_{2}
$$

The following empirical relation is proposed by Giggenbach (1984) to calculate the $\mathrm{CO}_{2}$ fugacity values in the range $100-350^{\circ} \mathrm{C}$ :

$\log f_{\mathrm{CO}_{2}}=0.0168 \cdot T\left({ }^{\circ} \mathrm{K}\right)-8.369$

By using relation (2), we calculate $\mathrm{CO}_{2}$ fugacities of $10^{-0.7}$ to $10^{0.5}$ at 180 and $260^{\circ} \mathrm{C}$, respectively. These values, in good agreement with those reported in Chiodini and Marini (1988), were imposed in our high-temperature model runs.

Oxygen fugacity $\left(\mathrm{f}_{\mathrm{O} 2}\right.$ ) was not an externally fixed in our simulations, and was left to vary during the reaction progress from its original value in the initial solution (cf. Section 5.1.1).

\subsubsection{Initial solutions}

Chemical and isotopic measurements on Ischia's thermal water discharges clearly indicate that hydrothermal reservoir fluids (both shallow and deep; see Fig. 1) are originally mixtures of local meteoric water and seawater (cf. Section 4.1) (Panichi et al., 1992; Inguaggiato et al., 2000; Aiuppa et al., 2006; Morell et al., 2008; Di Napoli et al., 2009, 2011). As demonstrated by combined geochemical-geophysical observations (Di Napoli et al., 2011), mixing proportions between the two contributing components vary over the island, depending on distance from the seashore and local hydrological/structural conditions. From concentrations of $\mathrm{Cl}$ and $\delta^{18} \mathrm{O}$ (two conservative parameters during mixing) in natural samples (Fig. 3a), we estimate seawater (sw) contributions in the mixtures ranging from $0 \%$ to $100 \%$. To make the effect of meteoric water-seawater mixing clearly visible in our diagrams, we have arbitrary grouped our samples into six main clusters of increasingly more saline (more seawater-like) waters, each characterized by a relatively narrow range of $\mathrm{Cl}$-concentrations (Fig. 3b).

The extent of meteoric water-seawater mixing upon infiltration governs the composition of recharge fluids entering the hydrothermal reservoir(s). To account for this effect, we used, as starting solutions for our EQ3/6 model runs, 6 different "initial solutions", each pertinent to one of the above described natural sample clusters, the 
Table 3

Chemical composition of the initial aqueous solutions used in the geochemical modeling.

\begin{tabular}{|c|c|c|c|c|c|c|}
\hline Species & $2 \% \mathrm{sw}$ & $8.5 \% \mathrm{sw}$ & $15 \%$ sw & $33 \%$ sw & $63 \%$ sw & $80 \%$ sw \\
\hline $\mathrm{Na}^{+}$ & 226 & 951 & 1676 & 3685 & 7032 & 8928 \\
\hline $\mathrm{K}^{+}$ & 8.4 & 35.3 & 62.2 & 136.6 & 260.7 & 330.9 \\
\hline $\mathrm{Mg}^{2+}$ & 27 & 114 & 201 & 442 & 843 & 1071 \\
\hline $\mathrm{Ca}^{2+}$ & 8.8 & 36.6 & 64.3 & 141.2 & 269.3 & 341.9 \\
\hline $\mathrm{Cl}^{-}$ & 407 & 1710 & 3013 & 6622 & 12639 & 16046 \\
\hline $\mathrm{NO}_{3}^{-}$ & $5.0 \times 10^{-6}$ & $5.0 \times 10^{-6}$ & $5.0 \times 10^{-6}$ & $5.0 \times 10^{-6}$ & $4.9 \times 10^{-6}$ & $4.9 \times 10^{-6}$ \\
\hline $\mathrm{SO}_{4}^{2-}$ & 56.9 & 239.6 & 422.3 & 928.2 & 1771.4 & 2248.9 \\
\hline $\mathrm{HCO}_{3}{ }^{-}$ & $9.0 \mathrm{E}-05$ & $2.2 \mathrm{E}-04$ & $3.4 \mathrm{E}-04$ & $6.9 \mathrm{E}-04$ & $1.3 \mathrm{E}-03$ & $1.6 \mathrm{E}-03$ \\
\hline $\mathrm{SiO}_{2}$ & 0.09 & 0.38 & 0.67 & 1.46 & 2.80 & 3.55 \\
\hline $\mathrm{Sr}^{2+}$ & 0.16 & 0.67 & 1.18 & 2.60 & 4.96 & 6.30 \\
\hline $\mathrm{Fe}^{3+}$ & $4.2 \times 10^{-5}$ & $1.8 \times 10^{-4}$ & $3.1 \times 10^{-4}$ & $6.9 \times 10^{-4}$ & $1.3 \times 10^{-3}$ & $1.6 \times 10^{-3}$ \\
\hline $\mathrm{Ba}^{2+}$ & $1.7 \times 10^{-5}$ & $1.7 \times 10^{-5}$ & $1.7 \times 10^{-5}$ & $1.7 \times 10^{-5}$ & $1.7 \times 10^{-5}$ & $1.8 \times 10^{-5}$ \\
\hline $\mathrm{Al}^{3+}$ & $2.7 \times 10^{-6}$ & $9.4 \times 10^{-6}$ & $1.6 \times 10^{-5}$ & $3.5 \times 10^{-5}$ & $6.6 \times 10^{-5}$ & $8.3 \times 10^{-5}$ \\
\hline Initial solution & $\mathrm{pH}$ at $15^{\circ} \mathrm{C}$ & & & & & \\
\hline $2 \%$ sw & 7.94 & & & & & \\
\hline $8.5 \% \mathrm{sw}$ & 9.49 & & & & & \\
\hline $15 \%$ sw & 9.57 & & & & & \\
\hline $33 \%$ sw & 9.66 & & & & & \\
\hline $63 \%$ sw & 9.64 & & & & & \\
\hline $80 \%$ sw & 9.68 & & & & & \\
\hline
\end{tabular}

$\%$ sw is the percentage (\% vol.) of seawater contribution to the mixing (see text). Concentrations of different species are in $\mathrm{mg} / \mathrm{l}$.

compositions of which are reported in Table 3: $2 \%, 8.5 \%$, $15 \%, 33 \%, 63 \%, 80 \%$ in vol. of seawater contribution to the mixing. These so-obtained model solutions were used as initial solutions for the $95-260{ }^{\circ} \mathrm{C}$ model runs described below. For clarity of data presentation, results of only 4 $(2 \%, 8.5 \%, 63 \%$ and $80 \%$ sw) over 6 model runs conditions are shown in the following Figures, and discussed throughout the manuscript.

\subsubsection{Solid reactants}

All model simulations were carried out by allowing irreversible reaction of initial solutions (cf. Section 5.1.1) with the assemblage of mineral phases listed in Table 4. The following phases were used as solid reactants to initialise our reaction path modelling simulations: sanidine $\left(\mathrm{Or}_{72} \mathrm{Ab}_{28}\right)$, plagioclase $\left(\mathrm{Ab}_{52} \mathrm{An}_{48}\right)$, a Fe-rich diopside $\left(\mathrm{Ca}_{0.9} \mathrm{Mg}_{0.8}\right.$ $\mathrm{Fe}\left({ }^{2+}\right)_{0.3} \mathrm{Si}_{2} \mathrm{O}_{6}$ ), biotite (annite $50 \%$, phlogopite $50 \%$ ), magnetite, zeolite (as pure heulandite), a smectite solid solution (see Appendix D), hematite (a proxy for the Fe-oxyhydroxides recurrently detected $-10 \%$ of the total groundmass and $\sim 6 \%$ of the whole rock - in MEGT0322) and gypsum. The above mineral compositions reflect mineral chemistry data on the MEGT0322 representative sample (Table 2). Table 4 also lists, for each of the selected solid reactants, the adopted specific surface areas and kinetic dissolution parameters, taken from a variety of literature sources. Attention was paid to select results of laboratory experiments performed on minerals of similar grain size as MEGT natural crystals. In the assumption that pore spaces are water-saturated, we used an effective inter-granular porosity of 0.5 (Calcaterra et al., 2004; Colella et al., $2009)$ to calculate the total volume of rock $\left(1222 \mathrm{~cm}^{3}\right)$ reacting with $1 \mathrm{~kg}$ of water solution. From this, the specific reacting mass for the different minerals (Table 4) was calculated from their modal proportions in MEGT0322 rock (Table 1).

\section{MODEL RESULTS}

\subsection{Dissolving primary minerals}

In our model runs, the primary MEGT minerals (both phenocrysts and in groundmass) dissolve irreversibly in proportions dictated by their abundances and dissolution rates (Eq. A2). Fig. 4a exemplifies the case of a typical model run $\left(T=95^{\circ} \mathrm{C}\right.$; initial solution: $\left.2 \% \mathrm{sw}\right)$, and shows the cumulative moles of dissolved minerals plotted against the reaction progress variable $\left(\log \xi_{i}\right)$. At all conditions explored, the reacting primary minerals dissolve more rapidly in the early steps of the model simulation $\left(-1000<\log \xi_{i}\right.$ $<-2$, thus producing an initial steep increase of destroyed mineral amounts. As more mature reaction stages (for $\left.\log \xi_{i}>-1\right)$ are attained, primary minerals appear to dissolve at more gentle rates. Gypsum, the most soluble species among the considered minerals, is totally dissolved at $\log \xi_{i}=-2$.

The various minerals contribute chemicals to the model solutions in proportions varying from one run to another. At $95{ }^{\circ} \mathrm{C}$ (and $2 \%$ sw initial solution; Fig. 4a), smectite, zeolite and plagioclase appear to dissolve most; whilst sanidine, diopside phenocrysts and hematite in groundmass are the least reactive minerals, followed by sanidine in groundmass and biotite and magnetite, both as phenocrysts and groundmass minerals.

While this mineral sequence is roughly maintained at all explored conditions, primary minerals are seen to dissolve more effectively at $260{ }^{\circ} \mathrm{C}$ than in $95^{\circ} \mathrm{C}$ runs. Comparison of $95^{\circ} \mathrm{C}$ and $260^{\circ} \mathrm{C}$ model runs (both initialised with 
Table 4

Specific surface areas and thermodynamic parameters in the kinetic equations in Appendix (Eq. A2) and (Eqs. A4)-(A6) used in the EQ3/6 simulations.

\begin{tabular}{|c|c|c|c|c|c|c|c|c|c|c|c|}
\hline \multirow[t]{2}{*}{ Mineral } & \multirow{2}{*}{$\begin{array}{l}\mathrm{mol} / \mathrm{kg} \\
\text { water (mol) }\end{array}$} & \multirow{2}{*}{$\begin{array}{l}\text { BET specific surface } \\
\text { area }\left(\mathrm{cm}^{2} \mathrm{~g}^{-1}\right)\end{array}$} & \multicolumn{3}{|c|}{ Acidic mechanism } & \multicolumn{2}{|c|}{ Neutral mechanism } & \multicolumn{3}{|c|}{ Basic mechanism } & \multirow[t]{2}{*}{ References } \\
\hline & & & $\begin{array}{l}\log k \\
\left(\mathrm{~mol} \mathrm{~m}^{-2} \mathrm{~s}^{-1}\right)\end{array}$ & $\begin{array}{l}E_{a} \\
\left(\mathrm{~kJ} \mathrm{~mol}^{-1}\right)\end{array}$ & $n_{\mathrm{H}}$ & $\begin{array}{l}\log k \\
\left(\mathrm{~mol} \mathrm{~m}^{-2} \mathrm{~s}^{-1}\right)\end{array}$ & $\begin{array}{l}E_{a} \\
\left(\mathrm{~kJ} \mathrm{~mol}^{-1}\right)\end{array}$ & $\begin{array}{l}\log \mathrm{k} \\
\left(\mathrm{mol} \mathrm{m}^{-2} \mathrm{~s}^{-1}\right)\end{array}$ & $\begin{array}{l}E \\
\left(\mathrm{~kJ} \mathrm{~mol}^{-1}\right)\end{array}$ & $n_{\mathrm{OH}}$ & \\
\hline \multicolumn{12}{|l|}{ Phenocrysts } \\
\hline Sanidine & 2.36 & 22 & -10.06 & 51.7 & 0.5 & -12.41 & 38 & -21.2 & 94.1 & -0.82 & $\begin{array}{l}\text { Palandri and Kharaka (2004) and } \\
\text { reference therein }\end{array}$ \\
\hline Plagioclase & 0.89 & 1116 & -8.88 & 53.5 & 0.54 & -11.47 & 57.4 & & & & $\begin{array}{l}\text { Palandri and Kharaka (2004) and } \\
\text { reference therein }\end{array}$ \\
\hline Diopside & 1.01 & 860 & -7.51 & 95.5 & 0.76 & & & & & & Chen and Brantley (1998) \\
\hline Biotite & 0.28 & 5000 & -9.84 & 22 & 0.53 & -12.55 & 22 & & & & $\begin{array}{l}\text { Palandri and Kharaka (2004) and } \\
\text { reference therein }\end{array}$ \\
\hline Magnetite & 0.29 & 1260 & -8.59 & 18.6 & 0.28 & -10.78 & 18.6 & & & & $\begin{array}{l}\text { Palandri and Kharaka (2004) and } \\
\text { reference therein }\end{array}$ \\
\hline \multicolumn{12}{|l|}{ Groundmass } \\
\hline Sanidine & 1.05 & 1116 & -10.06 & 51.7 & 0.5 & -12.41 & 38 & -21.2 & 94.1 & -0.82 & $\begin{array}{l}\text { Palandri and Kharaka (2004) and } \\
\text { reference therein }\end{array}$ \\
\hline Biotite & 0.16 & $2.00 \mathrm{E}+04$ & -9.84 & 22 & 0.53 & -12.55 & 22 & & & & $\begin{array}{l}\text { Palandri and Kharaka (2004) and } \\
\text { reference therein }\end{array}$ \\
\hline Magnetite & 0.34 & 1260 & -8.59 & 18.6 & 0.28 & -10.78 & 18.6 & & & & $\begin{array}{l}\text { Palandri and Kharaka (2004) and } \\
\text { reference therein }\end{array}$ \\
\hline Zeolite & 2.79 & 1715 & -7.8 & 58 & 0.7 & -11.8 & 58 & -10 & 58 & 0.3 & Ragnarsdòttir (1993) \\
\hline Smectite & 0.86 & $6.40 \mathrm{E}+05$ & -10.98 & 23.6 & 0.34 & -12.78 & 35 & -16.52 & 58.9 & -0.4 & $\begin{array}{l}\text { Palandri and Kharaka (2004) and } \\
\text { reference therein }\end{array}$ \\
\hline Hematite & 2.52 & 1060 & -9.39 & 66.2 & 1 & -14.6 & 66.2 & & & & $\begin{array}{l}\text { Palandri and Kharaka (2004) and } \\
\text { reference therein }\end{array}$ \\
\hline Gypsum & 0.00684 & 3000 & & & & -2.79 & 0 & & & & $\begin{array}{l}\text { Palandri and Kharaka (2004) and } \\
\text { reference therein }\end{array}$ \\
\hline
\end{tabular}

Masses of solid phases (mol/kg water) are derived from the modal abundances (Table 1). The BET specific surface areas are derived from literature data. The rate constant values (log $k$ ) are listed for dissolution at $T=25^{\circ} \mathrm{C}$ with the exception of Diopside which is referred at $T=90{ }^{\circ} \mathrm{C}$. Ea is the activation energy and $n H$ and $n O H$ are the orders of the reactions (Eqs. A4 and A6). 

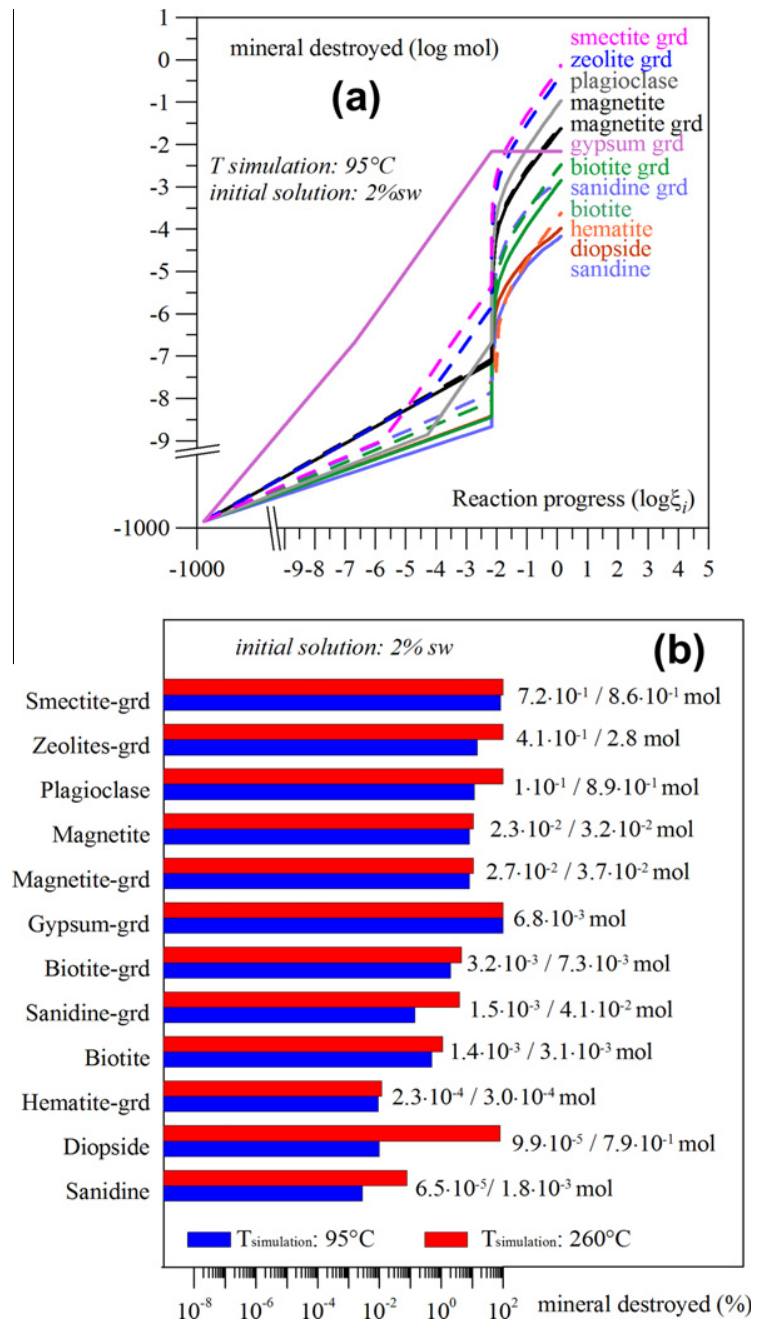

Fig. 4. (a) Molar amounts of primary minerals (listed in Table 4) dissolving into model solutions during a typical reaction path run at $95{ }^{\circ} \mathrm{C}$ (the $2 \%$ sw initial solution example is shown); (b) End-ofrun molar percentages of primary minerals destroyed in $95^{\circ} \mathrm{C}$ (blue bar) and $260{ }^{\circ} \mathrm{C}$ (red bar) model runs, both initialized with a $2 \%$ sw initial solution. Numbers on the right of each bar couples indicate the cumulative amounts (moles) of destroyed minerals at the end of reaction path $\left(95^{\circ} \mathrm{C} / 260^{\circ} \mathrm{C}\right)$. Results highlight that primary mineral dissolution is enhanced by increasing temperature.

$2 \%$ sw initial solution) (Fig. $4 \mathrm{~b}$ ) highlights that only $10 \%$ of the initial rock is titrated at $95^{\circ} \mathrm{C}$ at the end of the simulations $\left(\log \xi_{i}=0.11\right)$, whilst this amount increases to $44 \%$ at the higher temperature (end of the simulations $\log \xi_{i}=0.7$ ). Dissolution of diopside and sanidine is particularly favoured at high $\mathrm{T}$, increasing from 95 to $260^{\circ} \mathrm{C}$ by factors $\sim 10^{4}$ and $\sim 10^{2}$, respectively (Fig. $4 \mathrm{~b}$ ).

Overall, our model calculations suggest that sanidine phenocrysts, while being among the most abundant mineral phases ( $\sim 20 \%$ of whole rocks), contribute only marginally to hydrothermal reactions at Ischia: only $0.003-0.08 \%$ of the amount initially present is destroyed at the end of model runs (at any considered temperature and initial solution salinity). Instead, rock leaching is dominated, at least in our model calculations, by groundmass smectites and zeolites, and plagioclase phenocrysts (Fig. 4b). Smectites are seen to dissolve almost completely in all of our simulations, while zeolites and plagioclase are partially destroyed at $95{ }^{\circ} \mathrm{C}(12-15 \%$ of initial moles are destroyed at the end of run), and completely destroyed at $260{ }^{\circ} \mathrm{C}$ (compare Fig. $4 \mathrm{~b}$ and Table 4).

\subsection{Secondary minerals}

As reaction runs proceed, model solutions attain saturation relative to a variety of minerals. The EQ3/6 software would by default allow for precipitation of all solid phases existing in the thermodynamic database, and for which saturation has been reached. However, in order to confine our model computations to a finite number of "geologically significant" solutions, we restricted our list of potentially forming secondary minerals to those truly found in the alteration mineral assemblages of Ischia's intra-caldera MEGT units, or in similar hydrothermal settings (Table 5). The saturation state of these mineral phases in Ischia's thermal waters was carefully checked by performing preliminary speciation calculations on some selected samples.

The secondary mineral assemblage produced during our $95^{\circ} \mathrm{C}$ runs is illustrated in Fig. 5a and b. Comparison between the two plots demonstrates that the chemical composition of the initial solutions has only a marginal effect on the type and amount of secondary phases formed. Regardless of the initial solution's salinity, the following secondary phases are formed in $95^{\circ} \mathrm{C}$ model runs (listed in decreasing order of abundance): smectites (up to $1.8 \mathrm{~mol}$ ), carbonates (up to $0.2 \mathrm{~mol}$ ), and zeolites (up to $0.1 \mathrm{~mol}$ ). These are the characteristic mineral phases composing the Ischia's argillitic alteration facies $\left(T \sim 100{ }^{\circ} \mathrm{C}\right.$; Sbrana et al., 2009, 2010). The formed smectites are solid mixtures of mainly Mg-beidellite $(\sim 42 \%)$, Ca-beidellite $(\sim 25 \%)$ and Na-beidellite $(\sim 16 \%)$; orthorhombic carbonate is a solid mixture of strontianite $(\sim 73 \%)$, aragonite $(\sim 20 \%)$ and witherite $(\sim 7 \%)$, while trigonal carbonates are composed by calcite, magnesite and siderite $(\sim 65 \%, 31 \%$ and $4 \%$ respectively); finally, Ca-clinoptilolite $(\sim 53 \%)$, Na-clinoptilolite $(\sim 30 \%)$ and, in minor proportions, Sr-clinoptilolite $(\sim 13 \%)$ and K-clinoptilolite $(\sim 4 \%)$ make up the secondary zeolites.

In addition to the minerals above, a number of less abundant phases are formed in the $95^{\circ} \mathrm{C}$ model runs, including: (i) secondary dolomite (up to $\sim 10^{-2} \mathrm{~mol}$ ), at least in the most saline initial solutions (Fig. 5b); (ii) saponite (up to $5.4 \times 10^{-3} \mathrm{~mol}$ ), a solid mixture of mainly $\mathrm{Mg}$ saponite $(\sim 64 \%)$ and Ca-saponite $(\sim 23 \%)$; (iii) pyrite, anhydrite and barite (up to $\sim 10^{-3} \mathrm{~mol}$ ); (vi) cristobalite-alpha $\left(\sim 4 \times 10^{-3} \mathrm{~mol}\right)$, which appears in our EQ3/6 simulations only in the case of saline initial solutions (see Fig. 5b); more diluted aqueous solutions (e.g., $2 \% \mathrm{sw}$ ) are far from attaining saturation with respect to quartz polymorphs, and in such conditions silica is only removed by precipitation of silicate minerals (smectites, zeolites and kaolinite; Fig. 5a); (v) small amounts of ephemeral goethite, gibbsite and kaolinite (up to $\sim 10^{-4} \mathrm{~mol}$ ), appearing in the first reactions steps.

The secondary mineral assemblage produced by waterrock interactions at Ischia changes dramatically in response 
Table 5

Secondary minerals expected to form in model runs.

$T \sim 100^{\circ} \mathrm{C}(1,2,3,4,7)$

Argillitic alteration

$150<T<200{ }^{\circ} \mathrm{C}(3,7)$

Phyllitic alteration

220-265 ${ }^{\circ} \mathrm{C}(3,6,7,8)$

Propylitic alteration

\author{
Clay minerals (kaolinite) \\ Clay minerals (smectite) \\ Clay minerals (saponite) \\ Carbonates (calcite, dolomite) \\ Zeolites \\ Fe oxi-hydroxide \\ Sericite-muscovite \\ Silica \\ Sulphates (anhydrite) \\ Sulphides (pyrite) \\ Carbonates (calcite) \\ Clay minerals (chlorite) \\ Clay minerals (saponite) \\ Clay minerals (illite) \\ Feldspar (albite) \\ Sericite-muscovite \\ Silica (quartz) \\ Sulphates (anhydrite) \\ Sulphides (pyrite) \\ Carbonates (calcite) \\ Clay minerals (chlorite) \\ Clay minerals (saponite) \\ Feldspar (albite) \\ Feldspar (K-feldspar) \\ Silica (quartz) \\ Sulphides (pyrite)
}

Data from 5, 6, 7, 8

Data from 3, 4, 5, 6, 7, 8

Data from 5, 6, 7, 8

Data from 1, 2, 3, 5, 6, 8

Data from 1, 2, 3, 6, 8

Data from 4, 5

Data from 1, 2, 7

Data from 1, 2, 3, 4

Data from 1, 2

Data from 1, 2, 3

Data from 1, 2, 3, 6, 7, 8

Data from 1, 2, 3, 7

Data from 3

Data from 1, 2, 3, 6, 7, 8

Data from 3, 6, 8

Data from 7

Data from 1, 2, 3, 7

Data from 1, 2, 3

Data from 1, 2, 3, 6, 7, 8

Data from 1, 2, 3, 6, 7, 8

Data from 1, 2, 6, 7, 8

Data from 3

Data from 1, 2, 3, 6, 7, 8

Data from $1,2,3,6,7,8$

Data from 1, 2, 3, 7

Data from 1, 2, 3, 6, 7, 8

(1) De Vivo et al. (1989); (2) Caprarelli et al. (1997); (3) Fulignati et al. (1997); (4) Fulignati et al. (1998); (5) Brocchini et al. (2001); (6) Sbrana et al. (2009); (7) Ambrosio et al. (2010); (8) Sbrana et al. (2010).

to increasing temperatures, as indicated by results of our $180{ }^{\circ} \mathrm{C}$ (not shown) and $260{ }^{\circ} \mathrm{C}$ (Fig. 5e and f) model runs. Of particular relevance are the disappearance of kaolinite, zeolite and smectite (as beidellite), and the formation of newer clay minerals typical of phyllitic and propylitic alteration assemblages (Fulignati et al., 1997; Ambrosio et al., 2010), including Mg-rich chlorite (stable in both 180 and $260{ }^{\circ} \mathrm{C}$ model runs) and potassic illite (in $180^{\circ} \mathrm{C}$ simulations). Illite is replaced by secondary $\mathrm{K}$-feldspar in $260{ }^{\circ} \mathrm{C}$ model runs, and either one of the two K-bearing minerals remains stable until the end of the simulations, in coexistence with albite. As additionally shown by Fig. 5e and $\mathrm{f}$, the most abundant secondary phases produced in high-T model runs are quartz (up to $21 \mathrm{~mol}$ precipitated) and diaspore (up to $8.5 \mathrm{~mol}$ precipitated), which act as sinks for dissolved $\mathrm{Si}$ and $\mathrm{Al}$ (a role played at $95^{\circ} \mathrm{C}$ by smectite, zeolite and kaolinite; Fig. 5a and b). Up to $3.5 \mathrm{~mol}$ of carbonates (orthorhombic is $97 \%$ calcite and trigonal is $67 \%$ aragonite) are precipitated in the $180-260^{\circ} \mathrm{C}$ model runs, and a calcic saponite (molar fractions $\sim 0.80$ of saponite solid solution) is the only mineral of the smectite group precipitating in high- $\mathrm{T}$ runs (up to $0.3 \mathrm{~mol}$ ). As in lower- $\mathrm{T}$ simulations, small amounts of $\mathrm{Ba}-\mathrm{Sr}$-sulfates, pyrite and goethite are also formed at $260^{\circ} \mathrm{C}$.

Overall, results of $180-260^{\circ} \mathrm{C}$ model runs are consistent with the typical mineral alteration assemblages found in hydrothermal settings (Table 4) similar to Ischia. Forma- tion of secondary albite, illite-K and chlorite during our $180{ }^{\circ} \mathrm{C}$ simulations indicate that hydrothermal reactions in the Ischia's intermediate reservoir (Fig. 1) take place at conditions near the phyllitic to early propylitic alteration facies; whilst replacement of illite-K by K-feldspar, occurring in $260{ }^{\circ} \mathrm{C}$ model runs, is evidence for that hydrothermal alteration in propylitic facies occurs in the deepest and hottest reservoir (Fig. 1). Coexistence of albite and $\mathrm{K}$-feldspar in all $260^{\circ} \mathrm{C}$ model runs supports that cation exchange on alkali-feldspars becomes dominant at such conditions. Comparison of Fig. 5e and f, however, suggest that first appearance (stability) of secondary alkali-feldspars depends on composition (salinity) of initial solutions, and is overall delayed (depressed) at high salinity: this fact, which is even more visible in $80 \% \mathrm{sw}$ model runs at $260{ }^{\circ} \mathrm{C}$ (not shown), has marked effects on composition of model solutions (see below).

\subsection{Model solutions}

The $\xi$-dependent compositional evolution of model solutions in our $95-260{ }^{\circ} \mathrm{C}$ runs are shown in Figs. 3 and $6-8$. To verify the extent to which results of reaction path modelling offer a realistic representation of hydrothermal reactions occurring at Ischia, we compare in the Figures the compositions of model solutions and natural samples (Ischia's groundwaters). 

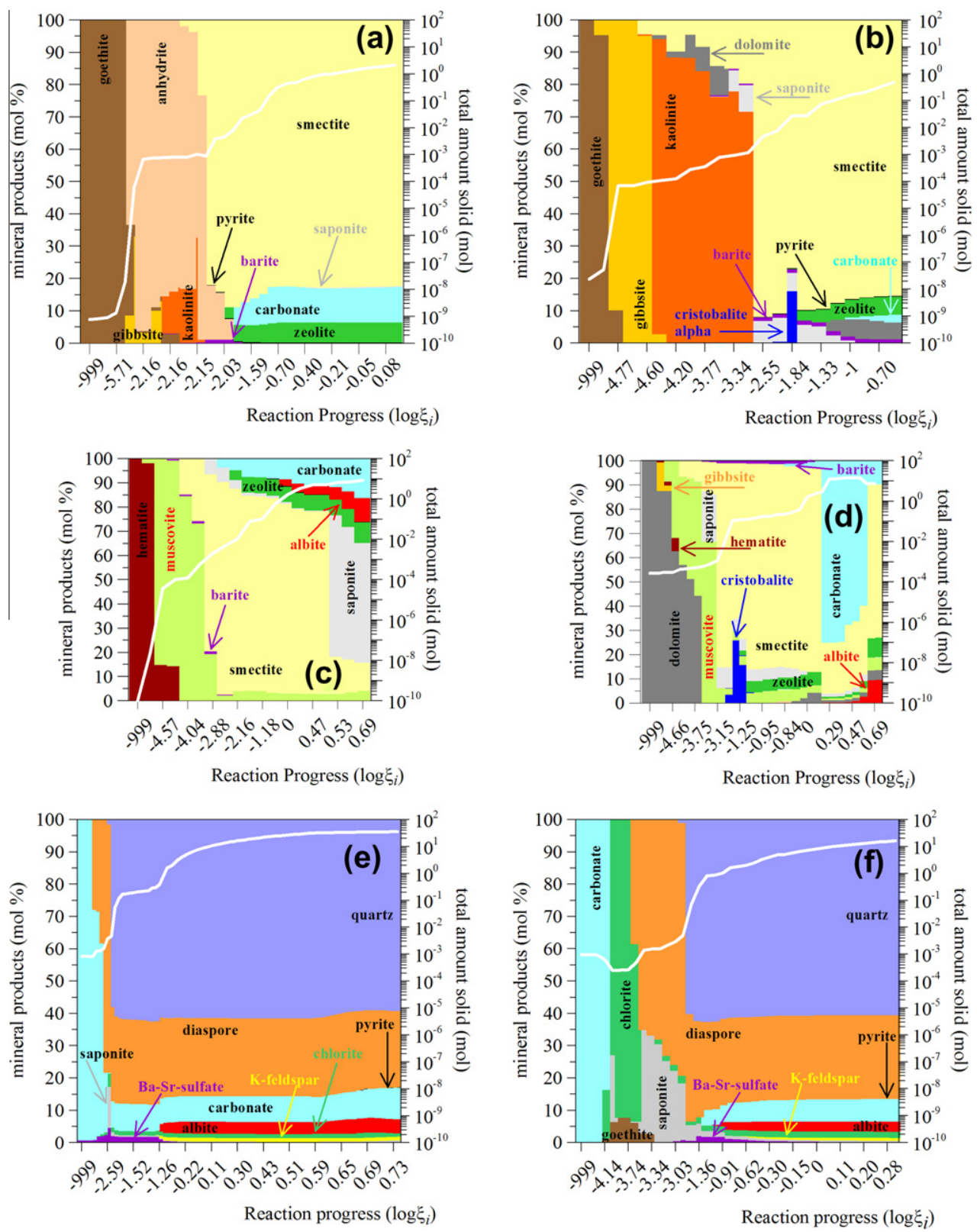

Fig. 5. Typical precipitation sequence of secondary solid phases precipitating during model runs: (a) $95{ }^{\circ} \mathrm{C}, 2 \%$ sw; (b) $95{ }^{\circ} \mathrm{C}$, $63 \%$ sw; (c) same as (a) but with muscovite and albite in the list of potentially precipitating minerals (see text; cf. Section 7.1); (d) same as (b) but with muscovite and albite in the list of potentially precipitating minerals (see text; cf. Section 7.1 ); (e) $260{ }^{\circ} \mathrm{C}, 2 \%$ sw; (f) $260{ }^{\circ} \mathrm{C}, 63 \%$ sw. In all diagrams, the $y$ scale gives the relative abundance (moles normalized to $100 \%$ ) of each solid phase in the secondary mineral assemblage formed at any given reaction progress value $\left(\log \xi_{i}\right)$. Simulations well reproduce, at any considered $T$, the typical secondary mineralogical assemblage observed in altered intra-caldera tuffs of Ischia Island (Sbrana et al., 2009, 2010) and other volcano-hosted hydrothermal systems (see Table 5).

A distinctive and long-known (Ellis, 1971) end-product of water-rock reactions occurring within hydrothermal systems is the progressive removal of $\mathrm{Mg}$ from aqueous solutions, and its entrapment in hydrothermal secondary minerals. Mg-depletion - relative to its initial contents in recharge (either meteoric or marine) fluids - is a peculiarity of hydrothermal solutions, and can be taken as a proxy for their "maturity" and, more generally, for the state-ofadvancement of mineral-solutions reactions (Giggenbach, 1988).
Figs. $3 \mathrm{~b}$ and 6 show that this hydrothermal Mg depletion trend is well reproduced by our model simulations. The diagrams show that, at all of the explored temperatures $\left(95-260{ }^{\circ} \mathrm{C}\right.$ range), model solutions become progressively Mg-poorer as reactions advance (e.g., with increasing of the reaction progress variable $\left.-\log \xi_{i}\right)$. Large $\mathrm{Mg}$-depletions are observed in case of reactions initialised with more dilute $(2-8.5 \%$ sw; Table 2$)$ initial solutions; in such conditions, $\mathrm{Mg}$ concentrations decrease of at least two orders of magnitude in the $95^{\circ} \mathrm{C}$ runs, and extremely 


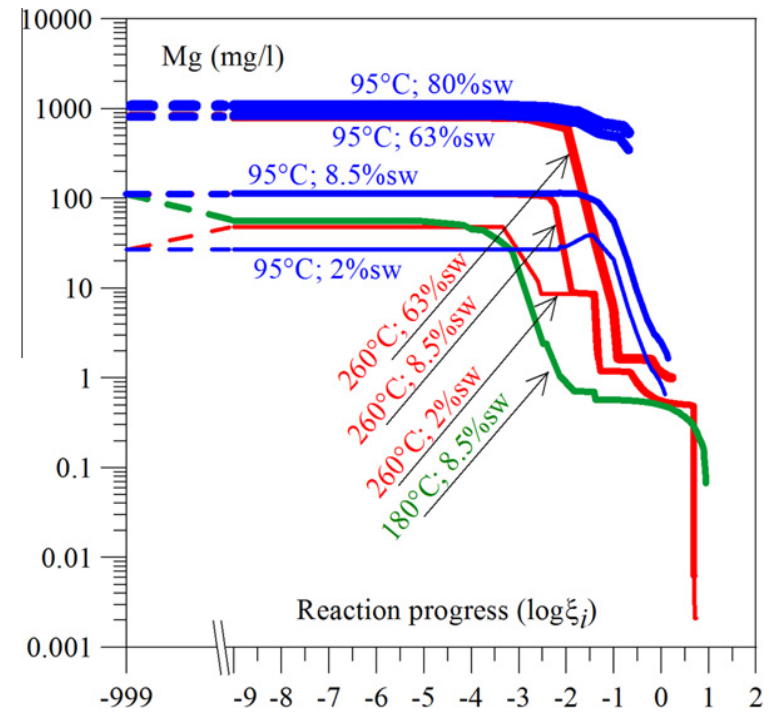

Fig. 6. Model evolution of $\mathrm{Mg}$ contents in aqueous solutions, plotted against the reaction progress variable $\left(\log \xi_{i}\right.$. In all run conditions ( $T$ range: $95-260^{\circ} \mathrm{C}$ ), a progressive $\mathrm{Mg}$-decreasing trend is observed in model aqueous solutions upon reaction advancement (Mg-depletion can therefore be used as a proxy for hydrothermal maturation in Figs. 7 and 8).

low $\left(0.001 \mathrm{mg}^{-1}\right) \mathrm{Mg}$ contents are obtained at $260{ }^{\circ} \mathrm{C}$ (Fig. 6).

In the assumption that $\mathrm{Mg}$ is a good proxy for the advancement of hydrothermal reactions, we use this element as a reference to investigate the behaviour of other dissolved species, which analytical (natural samples; Di Napoli et al., 2009) and modelled (model runs; this study) data are compared in Figs. 7 and 8 (note that, in drawing the diagrams, water samples are grouped into six clusters as in Fig. 3, and according to the procedure described in Section 5.1.1).

Fig. 7a reveals an overall consistency in Na contents between natural waters and model solutions. In our runs, $\mathrm{Na}$ contents are seen to invariably increase in the first reaction steps, when dissolution of primary minerals manifestly prevails over Na-removal by secondary minerals (mainly zeolites and smectites). At low salinities (e.g., for runs with $2 \%$ sw and $8.5 \%$ sw initial solutions; Fig. 7 a), this $\mathrm{Na}$ enrichment trend is particularly evident in the $95{ }^{\circ} \mathrm{C}$ model runs (where $\mathrm{Na}$ contents of $\sim 1000 \mathrm{mg}^{-1}$ or more are reached); whilst at higher temperatures $\left(180-260{ }^{\circ} \mathrm{C}\right.$ runs) model $\mathrm{Na}$ contents are seen to first increase, to then visibly decline upon reaction advancement (for $\log \xi_{i}>-2$ ), when secondary albite comes to play (Fig. 5e and f). Model trends are smoother in runs with $63-80 \%$ sw initial solutions (Fig. 7a), essentially because $\mathrm{Na}$ contribution from primary minerals is more marginal (initial solutions already have Na-content of 7000-9000 $\mathrm{mg}^{-1}$ ), and because appearance of secondary albite is delayed at high solution salinities (compare Fig. 5e and f).

The model evolution of dissolved $\mathrm{K}$ concentrations (Fig. 7b) mirrors that of $\mathrm{Na}$. In low salinity model runs, $\mathrm{K}$ contents initially increase for $\operatorname{low} \log \xi_{i}$ values, and then clearly decrease as K-bearing secondary minerals (zeolites and smectites a $95^{\circ} \mathrm{C}$; K-illite at $180{ }^{\circ} \mathrm{C}$; K-feldspar at $260^{\circ} \mathrm{C}$; Fig. $5 \mathrm{a}-\mathrm{b}$ and $\left.\mathrm{e}-\mathrm{f}\right)$ reach saturation and precipitate. Of particular note is that high-T $\left(180-260^{\circ} \mathrm{C}\right)$ low salinity model solutions are those better matching the whole $\mathrm{Na}-$ $\mathrm{K}-\mathrm{Mg}$ range of Ischia thermal waters, and particularly the compositions of the most "hydrothermally mature" waters (the Mg-poor thermal end-members of Di Napoli et al., 2009; stars A and B in Fig. 7a and b). Model runs at $95{ }^{\circ} \mathrm{C}$ typically yield to end-of-run model solutions which are far too $\mathrm{Mg}$-rich (and $\mathrm{K}$-poor) than these evolved natural samples. Potassium displays, instead, more conservative behaviour in high-salinity model runs (Fig. 7b), where it increases rather steadily at all investigated temperatures (again, because precipitation of K-bearing secondary minerals is delayed at high salinity; compare Fig. 5e and f).

While concentrations, and relative ratios, of sodium and potassium in Ischia groundwaters may to a large extent be determined by high-temperature $\left(T \sim 180-260^{\circ} \mathrm{C}\right)$ reactions (Fig. 7a and b), silica and iron contents seem to be mainly controlled by water-rock interactions at the shallow $\left(\sim 95^{\circ} \mathrm{C}\right)$ aquifer conditions (Fig. 8a and c). At any temperature and initial solution used, results of EQ3/6 runs show a rapid $\mathrm{SiO}_{2(\mathrm{aq})}$ increase in the first simulation steps (Fig. 8a), due to leaching of silicate primary minerals from the aquifer rocks. This initial phase is followed, in more evolved (higher $\log \xi_{i}$ ) reactions stages, by achievement of a constant $\mathrm{SiO}_{2 \text { (aq) }}$ value (from $\sim 100 \mathrm{mg}^{-1}$ at $95^{\circ} \mathrm{C}$ to $\sim 400 \mathrm{mg} \mathrm{l}^{-1}$ at $260{ }^{\circ} \mathrm{C}$ ), which reflects buffering of dissolved Si by precipitating secondary minerals (mainly smectites at low $\mathrm{T}$ and quartz at high $\mathrm{T}$ simulations; see Fig. 5a-b and e-f). The $95-180^{\circ} \mathrm{C}$ model trends perfectly overlap the chemical evolution of Ischia thermal waters (Fig. 8a). Model runs at $260{ }^{\circ} \mathrm{C}$, instead, manifestly over-estimate dissolved $\mathrm{SiO}_{2(\mathrm{aq})}$ contents of natural samples (Fig. 8a).

Iron is mostly supplied by leaching of smectite (as FeIII) and magnetite (as FeIII/II) from the MEGT units, and mainly scavenged by aqueous solutions by secondary smectite and pyrite and carbonate. The smectite/magnetite relative proportions in the mineral assemblage therefore control the $\mathrm{Fe}^{3+} / \mathrm{Fe}^{2+}$ release to model solutions. Sensitivity tests we performed, by changing both the nontronite content of the smectite and the smectite/magnetite abundances in the primary mineral assemblage, proved however to only marginally affect the redox evolution ( $\mathrm{Fe}$ content and Eh) of model solutions. Comparison between model and natural solutions (Fig. 8b and c) supports the idea that dissolved iron concentrations in Ischia thermal waters are mainly controlled by hydrothermal reactions at shallow reservoir conditions $\left(95^{\circ} \mathrm{C}\right)$. There is, in fact, a good agreement between measured (natural waters) and modelled (model solutions) at $95^{\circ} \mathrm{C}$, whilst model runs at 180 and $260{ }^{\circ} \mathrm{C}$ underestimate measured $\mathrm{Fe}$ contents in Ischia thermal waters (except at high salinity). During our $95^{\circ} \mathrm{C}$ model runs, redox conditions of model solutions evolve from oxidising $(\mathrm{Eh} \sim>200 \mathrm{mV})$ to reducing $(\mathrm{Eh} \sim-200 \mathrm{mV})$ (Fig. 8c) as a consequence of reactions taking place in the hydrothermal envelope. These increasingly reducing redox conditions promote iron release to leaching solutions, leading to a net increase in dissolved $\mathrm{Fe}$ at the end of model runs. Natural Ischia water samples plot nicely along the 

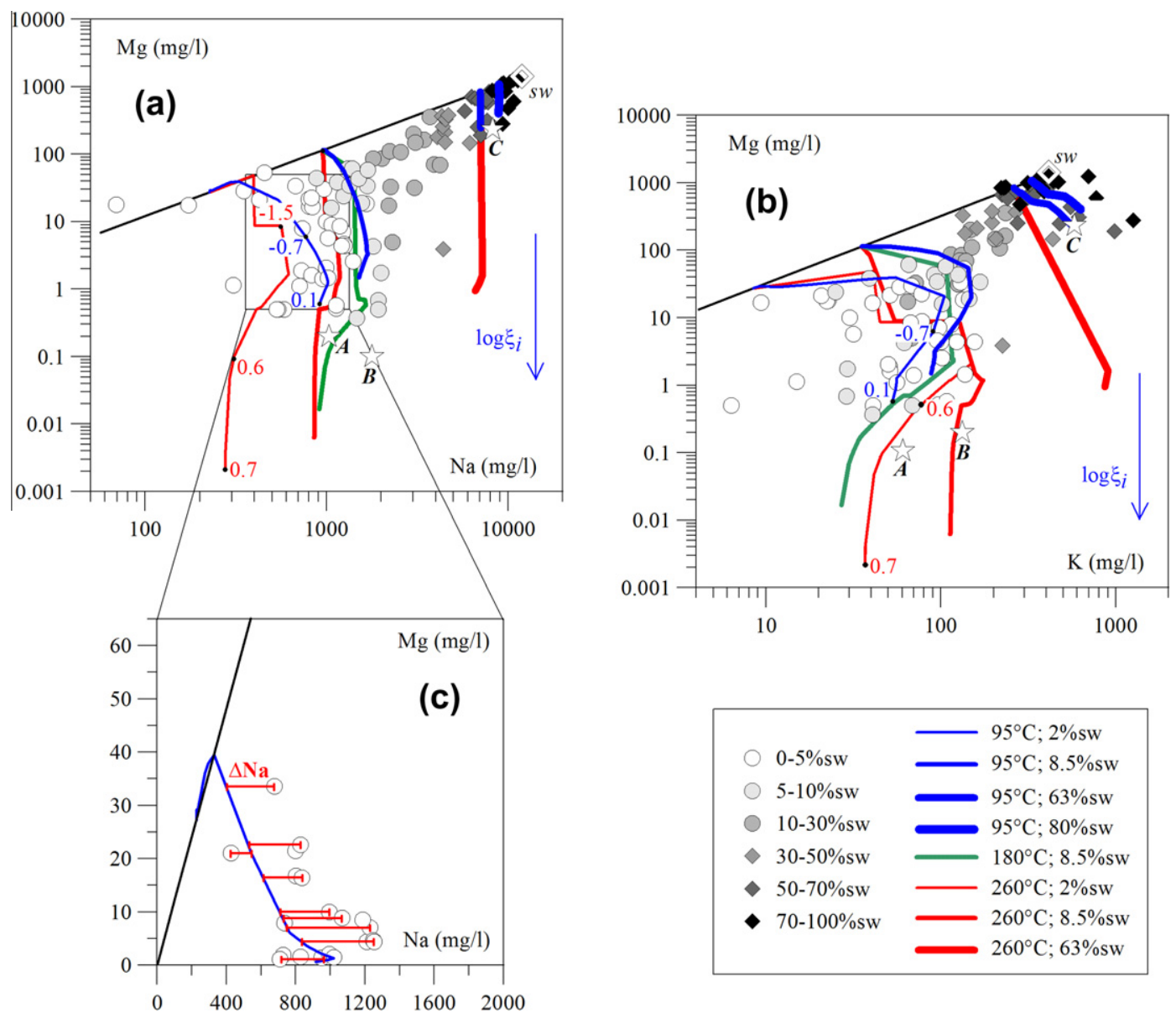

Fig. 7. Natural (Ischia's thermal water samples; from Di Napoli et al., 2009) and modelled aqueous solutions (solid lines) at match. (a) Mg vs. $\mathrm{Na}$; (b) Mg vs. K. In both diagrams, symbols for natural samples are as in Fig. 3 and stars (A, B and C) indicate the Ischia's hydrothermal endmembers (cf. Section 4.1) identified by Di Napoli et al. (2009). Solid lines describe the model-derived evolution of aqueous solutions upon hydrothermal reaction over a range of conditions (see legend). The advancement of reaction is indicated by numbers $\left(\log \xi_{i}\right)$ along each model curve; (c) Detail of (a), describing the statistical procedure used to quantitatively assess the effectiveness of model runs in reproducing natural compositions. In the Figure, we compare the compositions of model solutions obtained in the $95{ }^{\circ} \mathrm{C}$ (initial solution: $2 \%$ sw) model run with compositions of Ischia's thermal water of similar salinity (e.g., reflecting seawater contributions to the mixture of $2 \pm 1 \%$; see Fig. 3). For each thermal water sample, we estimated a "distance" from the model curve as: $\Delta \mathrm{Na}(\%)=100 \cdot\left(\mathrm{Na}_{\text {sample }}-\mathrm{Na}_{\text {model }}\right) / \mathrm{Na}_{\text {model }}$. This coefficient averaged at $23 \pm 13 \%$ in the specific case of Fig. 7c. This procedure was extended to all runs and major elements, demonstrating that natural samples are reproduced by model results within a factor $8-30 \%$ (the lowest errors are observed in high salinity runs).

$95^{\circ} \mathrm{C}$ model trends of Fig. $8 \mathrm{~b}$ and c, while being far more oxidizing than high-T $\left(180-260{ }^{\circ} \mathrm{C}\right)$ model calculations would suggest.

Reaction paths simulated in the $95-260{ }^{\circ} \mathrm{C}$ range show model $\mathrm{SO}_{4}$ contents (Fig. 8d) which agree well with the trends exhibited by Ischia water samples. As a matter of fact, at any considered salinity, seawater represents the most significant source of dissolved sulphate in Ischia groundwaters (the absence of S-rich steam-heated groundwaters on the island was already evidenced by Di Napoli et al., 2009). However an additional $\mathrm{S}$ contribution from leaching of gypsum in MEGT justifies the $\mathrm{SO}_{4}$ enrichments observed in early reaction path stages (Fig. 8d). As a consequence of further water-rock interactions, dissolved $\mathrm{SO}_{4}$ contents are then forced to decrease by formation of newforming secondary minerals, such as anhydrite, $\mathrm{Ba}-\mathrm{Sr}-$ sulphates and pyrite (Fig. 5).

\section{GENERAL DISCUSSION}

A full understanding of the complex gas-water-rock interactions taking place within hydrothermal systems requires modelling of the complex mass exchanges between minerals and fluid phase(s). Our results here indicate that application of reaction path modelling, while requiring a number of independent constraints (structure of the system, mineralogy of primary rocks and alteration minerals, etc.) to be properly set, provides a variety of key information on the hydrothermal system under study.

One first significant - and somewhat unexpected - result of our calculations is that leaching of aquifer rocks would be dominated at Ischia by alteration mineral phases such as smectites and zeolites, rather than by primary minerals (Fig. 4). This fact may to some extent reflect the peculiar situation of Ischia, where MEGT units have long remained in 

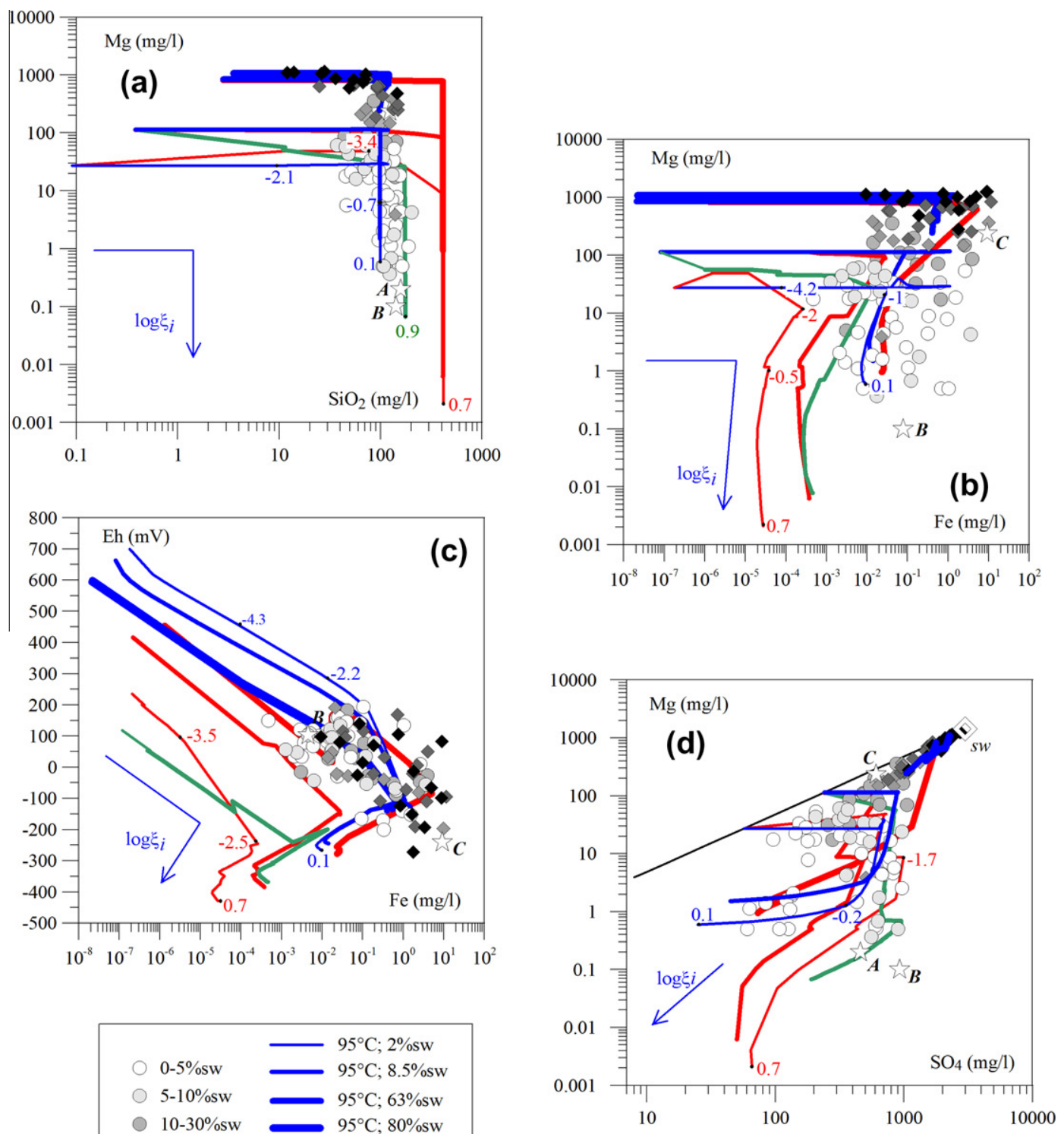

Fig. 8. Natural (Ischia's thermal water samples; from Di Napoli et al., 2009) and modelled aqueous solutions (solid lines) at match. (a) Mg vs. $\mathrm{SiO}_{2}$; (b) $\mathrm{Mg}$ vs. Fe; (c) Eh vs. Fe; (d) $\mathrm{Mg}$ vs. $\mathrm{SO}_{4}$. Symbols and lines as in Figs. 3 and 7.

contact with seawater after their deposition when the island subsided (forming the MEGT caldera), leading to pervasive alteration. Yet, we believe that dissolution of alteration minerals can remain a highly significant (though often overlooked) process at many long-lived hydrothermal systems, where present-day infiltration waters interact with rocks having been altered by hydrothermal fluids for centuries, or even millennia.

During the model runs, the chemicals made available by rock dissolution are partitioned between the aqueous solution and any secondary mineral reaching saturation. It follows that careful examination and choice of the set of secondary minerals the software is allowed to form is critical to a realistic representation of the hydrothermal water evolution. Our results indicate that, when realistic sets of secondary mineral assemblages are selected (Table 5 and Fig. 5), these reflecting well the range of alteration mineral facies in hydrothermal environments, the modelled solutions have compositions which agree well with natural data (Figs. 3 and 6-8). We used simple statistical arguments, the rationale of which is illustrated in Fig. 7c, to assess that compositions of natural (water) samples are reproduced by our models within a factor $8-30 \%$.

Results of our reaction path models show that only chlorine concentrations remain nearly constant during model runs (Fig. 3b), an hint for that dissolved $\mathrm{Cl}$ in aqueous 


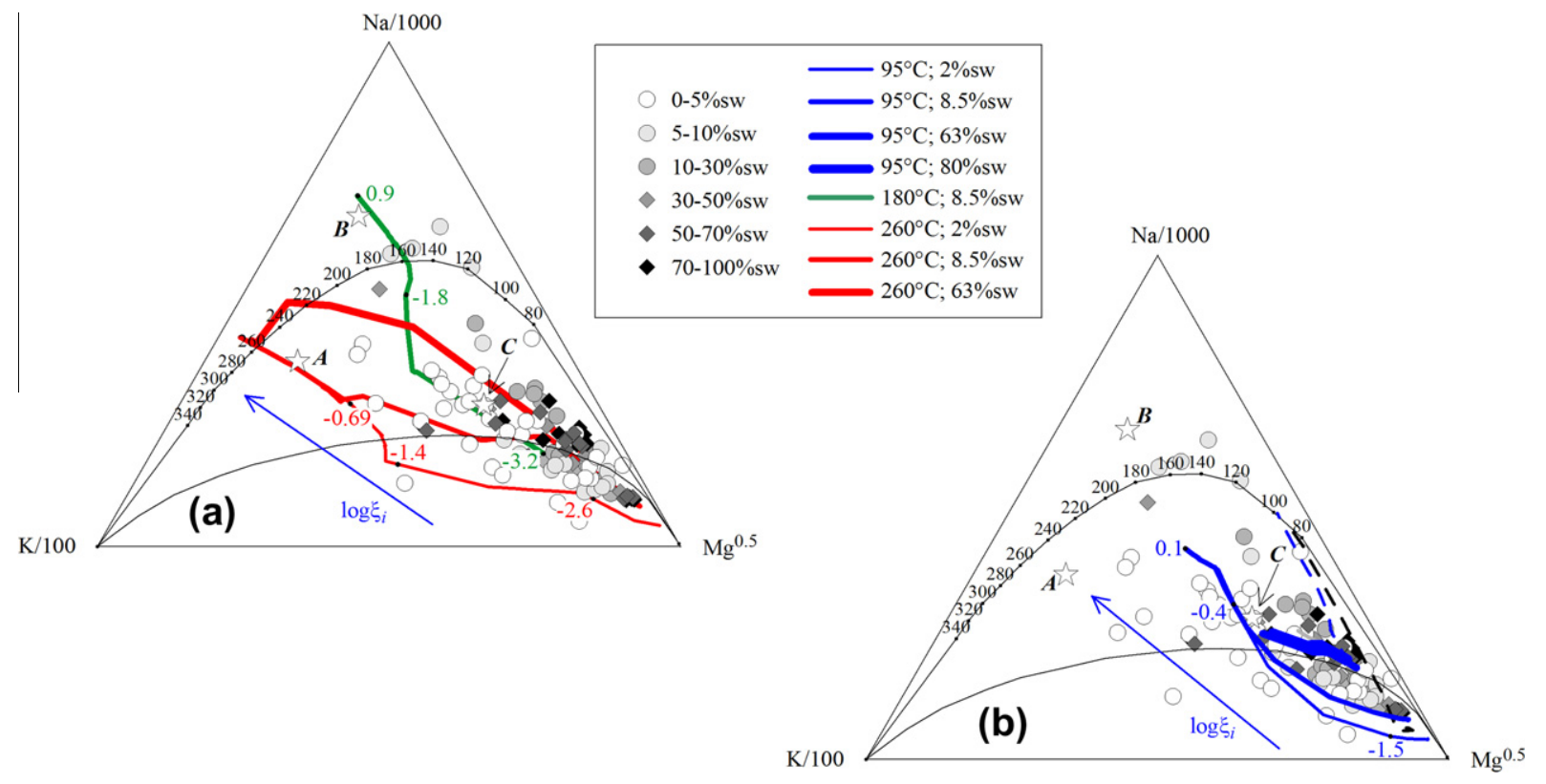

Fig. 9. A modified version of the Giggenbach's (1988) triangular diagram showing the distance from equilibrium ("maturation degree") of Ischia thermal water samples (from Di Napoli et al., 2009). Symbols, lines and stars as in Figs. 3 and 7. (a) High-temperature (180-260 ${ }^{\circ} \mathrm{C}$ ) model runs (green and red curves; calculated in range of initial solutions' salinities: 2, 8.5 and $63 \% \mathrm{sw}$ ) satisfactorily reproduce (in terms of Na/ $\mathrm{K}$ and $\mathrm{K} / \mathrm{Mg}$ ratios) the chemical features of "fully mature waters" indicated by Di Napoli et al. $(2009,2011)$ as Ischia's hydrothermal endmembers (A, B and C stars). (b) Solid blue curves, representing the chemical evolutions of model solutions at $95{ }^{\circ} \mathrm{C}$ (initialised with $2-80 \% \mathrm{sw}$ initial solutions), well fit the $\mathrm{Na}-\mathrm{K}-\mathrm{Mg}$ compositions of natural Ischia's samples in earlier stages of water-rock interaction process ("immature waters"). These model runs were performed with muscovite/K-feldspar and albite being suppressed from the list of potentially forming secondary minerals. Dashed lines are shown for comparison, displaying compositions of model solutions obtained in identical conditions $\left(T=95^{\circ} \mathrm{C} ; 2\right.$ and $80 \%$ sw initial solutions) but with muscovite/K-feldspar and albite included in the list of potentially forming secondary minerals. $\log \xi_{i}$ values drawn in the curves as in Fig. 3 and Figs. 7 and 8.

solutions are only fixed by initial mixing proportions between meteoric water and seawater (Fig. 3a). By contrast, the remaining dissolved species in Ischia groundwaters show large variations, and spread over a range un-reproducible by meteoric-water mixing (Figs. 6-8): fluid-mineral reactions are therefore decisive in determining their behaviour.

The strong temperature dependence of $\mathrm{Mg}$ contents in thermal surface discharges has long been recognized, and generally ascribed to equilibration of hydrothermal solutions with chlorite (Ellis, 1971) or Mg-rich clays for with chlorite may serve as a thermodynamic proxy. This $\mathrm{Mg}-$ depletion trend upon hydrothermal reaction is well observed in our model runs at all explored temperatures and salinities (Fig. 6). The model evolutions of other dissolved constituents show, instead, more contrasted behaviour during our simulations (Figs. 7 and 8), with concentrations initially increasing during early reaction steps (low $\log \xi_{i}$ ), and then typically decreasing (at high $\log \xi_{i}$ ) as secondary minerals come to play.

One significant outcome emerging from comparison between natural and model solutions is that natural abundances of $\mathrm{SO}_{4}, \mathrm{SiO}_{2}$ and $\mathrm{Fe}$ are best reproduced by lowtemperature $\left(95^{\circ} \mathrm{C}\right.$ ) model runs (Fig. 8), indicating that these elements are buffered by reactions occurring in the shallowest parts of the hydrothermal system. In contrast, the Na-K-Mg compositions of several Ischia water samples, and particularly of the Ischia's thermal end-members (cf. Section 4.1) described by Di Napoli et al. (2009) (stars in Figs. 7 and 8), can only be reproduced in high-temperature model runs: only at $180-260^{\circ} \mathrm{C}$, model solutions achieve the typical $\mathrm{Mg}$-poor and $\mathrm{K}$-rich composition required to fit with natural samples. It is therefore concluded that the cation contents of several (most) surface water discharges preserve memory of quenched equilibria attained deep at reservoir(s) conditions. The validity of this conclusion, an obvious pre-requisite for the use of classic solute geothermometers, is tested further below.

\subsection{Clues from the Giggenbach's (1988) triangular diagram}

An universally used graphical tool to evaluate the "maturation degree", or distance from equilibrium, of hydrothermal solutions is the Giggenbach's (1988) triangular diagram, a simplified version of which is given in Fig. 9. In such diagram, "immature waters", or fluids in initial stages of hydrothermal interactions because of shallow/fast circulation in the hydrothermal envelop, typically plot close to the $\mathrm{Mg}$ corner. By contrast, when recharge fluids percolate (and long reside) deep within the hydrothermal system, the resulting extensive (prolonged) water-rock interactions lead to a sequence of dissolution reactions of primary minerals - and deposition of secondary minerals - overall forcing hydrothermal solutions to diverge from the $\mathrm{Mg}$ corner, 
to become increasingly more alkali $(\mathrm{Na}$ and $\mathrm{K})$ rich (Giggenbach, 1988). The final stage of such "maturation path" is the so-called "full equilibrium" (Giggenbach, 1988), which corresponds to a state in which fluids have attained equilibrium with a mineral assemblage composed of alkali-feldspars, Mg-chlorite and silica (Giggenbach, 1984). In such conditions, and at geothermally relevant temperatures $\left(>150^{\circ} \mathrm{C}\right)$, the relative $\mathrm{Na}$ to $\mathrm{K}$ proportions of thermal waters are buffered, and therefore univocally fixed, by full-equilibrium with coexisting secondary albite and Kfeldspar, via the following cation exchange reaction:

$\mathrm{Na}$-feldspar $+\mathrm{K}^{+} \leftrightarrow \mathrm{K}$-feldspar $+\mathrm{Na}^{+}$

Observations on deep geothermal well discharges (White, 1957; Ellis and Wilson, 1960; Ellis and Mahon, 1964) have provided general support to model expectation dictated by equilibrium (3) (Giggenbach, 1988), demonstrating preferential $\mathrm{K}$ partitioning (relative to $\mathrm{Na}$ ) into hydrothermal solutions with increasing temperature (e.g., a decrease of $\mathrm{Na} / \mathrm{K}$ ratios on increasing reservoir $\mathrm{T})$.

With the final goal to add confidence on results of our reaction path simulations, we use the Giggenbach's (1988) triangular diagram (Fig. 9) to test the ability of our calculations to quantitatively reproduce the general maturation track of hydrothermal fluids. When the solutions resulting from our $95-260^{\circ} \mathrm{C}$ model runs are drawn in Fig. 9 (see curves), the hydrothermal maturation trends emerge clearly: all model solutions are $\mathrm{Mg}$-rich at very early simulation stages, and then rapidly evolve towards the full-equilibrium line upon advancement of reaction, as $\mathrm{Mg}$-bearing secondary minerals are being formed (see Fig. 5). The hydrothermal maturation track follows different paths in the different simulations (see curves in Fig. 9), however, demonstrating a strong dependence on temperature and composition (salinity) of the initial solution, as detailed below.

In Fig. 9a, four different model curves are shown, each describing the evolution (in terms of $\mathrm{Na}, \mathrm{K}$ and $\mathrm{Mg}$ contents) of an aqueous solution interacting at high temperature (either 180 or $260^{\circ} \mathrm{C}$ ) with the Ischia's characteristic mineral assemblage (Table 4). The accent is put on low salinity fluids (i.e., initial solutions $2 \%$ and $8.5 \%$ sw; Table 3 ) in view of the evidence (Di Napoli et al., 2009) of a dominantly meteoric nature of the deep hydrothermal reservoirs (see Fig. 1). However, in order to characterise the dependency of model results on initial salinity, and because some more saline thermal fluids (the Citara thermal end-member of Di Napoli et al., 2009) have also been identified, results for a $260{ }^{\circ} \mathrm{C}$ model run - using the $63 \%$ sw initial solution are also shown.

In the entire range of initial solution salinities explored (Fig. 9a), the $180-260^{\circ} \mathrm{C}$ model paths invariantly display somewhat overlapping linear trends in the initial model reaction steps: in such early stages of the reaction path, $\mathrm{Na}$ and $\mathrm{K}$ are added to model solutions in proportions close to those of the bulk MEGT host rock (the minor differences in the slopes of the 4 different model trends do reflect the range of $\mathrm{Na} / \mathrm{K}$ ratios in starting aqueous solutions). In later model stages of water-rock reaction, however, the model curves manifestly diverge, as the T-dependent sequence of appearance of precipitating secondary solid phases (see Fig. 5) leads to dissimilar buffering of dissolved $\mathrm{Na}$ and $\mathrm{K}$ contents. Clear breaks in the slopes of model curves correspond, in fact, to first appearance of specific alkali-bearing secondary minerals: (i) in the $180^{\circ} \mathrm{C}$ model run, the two kinks in the curve reflect secondary K-illite (first slope variation; Fig. 9a) and albite (second slope variation of $180{ }^{\circ} \mathrm{C}$ curve; Fig. 9a); (ii) at $260^{\circ} \mathrm{C}$ instead, model curves display a first characteristic break-in-the-slope when solutions attain a partial equilibrium state ("partial equilibrium field" in Fig. 9a), caused by secondary albite precipitation (Fig. 5e and f), whilst a second break-in-the-slope marks secondary K-feldspar formation (Fig. 5e and f). Comparison of the three $260^{\circ} \mathrm{C}$ model curves interestingly confirm (Giggenbach, 1988) that albite formation is apparently delayed (occurring at high $\log \xi_{i}$ during the reaction) with increasing salinities: in the $63 \% \mathrm{sw}$ model run (thick red curve; Fig. 9a), albite only precipitates when the "full equilibrium" curve is intercepted by our model solution evolutionary curve.

In all $180-260^{\circ} \mathrm{C}$ model runs, coexistence of secondary albite and $\mathrm{K}$-feldspar in the final stages of the simulations fix the model solutions $\mathrm{Na} / \mathrm{K}$ ratios at values which agree well with those distinctive of attainment of water-feldspar equilibrium (Eq. (3)) at the considered T. This confirms that the full equilibrium state of hydrothermal reactions is well reproduced by our simulations. In addition, a good fit between model hydrothermal paths (model curves) and compositions of chemically "mature" (e.g., above the "partial equilibrium curve") Ischia thermal waters is recognized in Fig. 9a. This Figure shows, in particular, that our model runs satisfactorily reproduce the $\mathrm{Na}-\mathrm{K}-\mathrm{Mg}$ compositions of the Ischia's "thermal end-members" (stars A, B and C in Figs. 7-9) which were indicated by Di Napoli et al. (2009) as those most representative of equilibrium conditions in deep hydrothermal reservoirs. More in the specific, our runs at $260{ }^{\circ} \mathrm{C}(2-8.5 \%$ sw initial solution $)$ generate endof-run model solutions fitting well the cation composition of the Casamicciola thermal end-member (A in Fig. 9a), for which an equilibrium temperature of $254{ }^{\circ} \mathrm{C}$, and an essentially meteoric origin, have been postulated (Fig. 1) (Di Napoli et al., 2009). On the other hand, the composition of the Serrara thermal end-member (B in Fig. 9a), which according to Di Napoli et al. (2009) would be the surface discharge of fluids rising from the intermediate ( $T \sim 150-200^{\circ} \mathrm{C}$ ) hydrothermal reservoir (see Fig. 1), is well reproduced in the final steps of the $180{ }^{\circ} \mathrm{C}$ model run. The same Fig. 9a also shows a more ambiguous situation for the Citara thermal end-member of Di Napoli et al. (2009) (C in Fig. 9a): since this water sample plots far from the full-equilibrium line, its composition can be matched well by either the $95^{\circ} \mathrm{C}$ (see below), $180{ }^{\circ} \mathrm{C}$ (indeed, Di Napoli et al. (2009) interpreted this fluid as derived from the intermediate $150 / 200{ }^{\circ} \mathrm{C}$ hydrothermal reservoir, followed by near-surface seawater dilution) or $\sim 260^{\circ} \mathrm{C}$ model runs.

The solid curves in Fig. $9 \mathrm{~b}$ represent the $\mathrm{Na}-\mathrm{K}-\mathrm{Mg}$ compositions of model solutions obtained during a number of different $95^{\circ} \mathrm{C}$ model runs, initialised with initial 
solutions of 2, 8.5, 63 and $80 \%$ sw, respectively. One significant - but somewhat questionable - aspect of such simulations is the potential formation of albite, muscovite and/or $\mathrm{K}$-feldspar. These mineral phases, if allowed to form during our model simulations, would in fact precipitate in all $95^{\circ} \mathrm{C}$ runs (see Fig. 5c and d). This is not surprising since, as activity diagrams (not shown) demonstrate, these mineral phases are thermodynamically stable in the temperaturecompositional domain of Ischia's thermal groundwaters. However, that albite, K-feldspar and muscovite are truly formed in the natural Ischia's environment is doubtful. Mineralogical observations on hydrothermal alteration facies indicate that formation of secondary albite and $\mathrm{K}$-feldspar only takes place at temperatures higher than $150{ }^{\circ} \mathrm{C}$ (Muffler and White, 1969; Naboko, 1970; Browne and Ellis, 1970; Browne, 1978); and secondary feldspars have never been detected in the argillitic alteration facies at both Ischia (Sbrana et al., 2009, 2010; this work) and nearby Campi Flegrei (De Vivo et al., 1989; Caprarelli et al., 1997) (Table 5). Muscovite, and its proxy sericite, are common low-T secondary minerals in hydrothermal alteration of felsic rocks (Creasey, 1966; Meyer and Hemley, 1967; Rose, 1970; Lowell and Guilbert, 1970; McDowell and Elders, 1980; Que and Allen, 1996; Deer et al., 1997), and have been identified in the argillitic alteration facies of nearby Phlegrean Field (Caprarelli et al., 1997). However, muscovite has not been detected in hydrothermally altered tuffs of Ischia (Sbrana et al., 2009, 2010), and, if allowed to form during model runs, would force model solutions to become largely K-depleted, a fact which is not observed in natural samples.

For the reasons above, we consider the solid curves in Fig. 9b, which were obtained using the typical secondary minerals of the Ischia's argillitic alteration facies ( $T \sim 100{ }^{\circ} \mathrm{C}$; Sbrana et al., 2009, 2010; see Table 5) - and therefore with albite, muscovite and K-feldspar suppressed from the list of the potentially forming secondary minerals - as the most realistic of the natural Ischia's environment. In such conditions, with reaction (Eq. (3)) being prevented to occur, water-rock interactions remain far from equilibrium: the full-equilibrium line is never achieved by our simulations (Fig. 9b), and the $\mathrm{Na} / \mathrm{K}$ ratios of model solutions, if projected to intersect the full-equilibrium line, would lead to unrealistically high temperatures (180$200{ }^{\circ} \mathrm{C}$ ). Indeed, the evolution of dissolved $\mathrm{Na}$ and $\mathrm{K}$ in such $95{ }^{\circ} \mathrm{C}$ model runs is being controlled by precipitation of secondary zeolite and smectites (Fig. 5a and b), and can in no way be used in combination with (Eq. (3)) in the feldspar geothermometer.

That feldspars are essential ingredients for waterreaction to go to completion (e.g., for equilibrium to be attained) is confirmed by results of two model runs at $95^{\circ} \mathrm{C}$ (initialised with 2 and $80 \%$ sw initial solutions; black and blue dotted lines, respectively) in which feldspars and muscovite were left free to form. In such conditions, model reactions advance to intersect the full equilibrium line at temperatures $\left(80-100^{\circ} \mathrm{C}\right)$ consistent with model run conditions. However, none of the Ischia's thermal waters fall along these "feldspar-in" model curves. This additionally proves that precipitation of feldspars and muscovite, while thermodynamically possible, is actually not occurring in the Ischia's shallow hydrothermal environment (see Table 5). Most Mg-rich Ischia's thermal waters (e.g., those sample plotting at or below the partial equilibrium line of Fig. 9b) plot nicely above the "feldspar-out" model curves (solid curves), evidencing that equilibrium conditions are far from being achieved in the shallow $\left(95^{\circ} \mathrm{C}\right)$ Ischia's hydrothermal system. This may reflect either kinetic effects (rapid groundwater transit in the shallow aquifer), or complex hydrological conditions (e.g., recurrent mixing with recharge of deep-rising thermal fluids) during hydrothermal circulation.

\section{CONCLUSIONS}

Reaction path modelling, when correctly initialised with independent constraints on (primary and secondary) minerals chemistry/abundance and $\mathrm{T}-\mathrm{X}$ conditions, offers a realistic and powerful representation of hydrothermal processes. Our study here, in particular, demonstrates that the compositions of surface discharges can be adequately reproduced by model simulations, providing additional confidence on the use of reaction path modelling in hydrothermal contexts. Even more significantly, all main aspects of hydrothermal reactions are accounted for by our model calculations, including (i) the progressive Mg-depletion in hydrothermal solutions upon reaction; (ii) the $\mathrm{T}$-dependent buffering of $\mathrm{Na} / \mathrm{K}$ ratios of aqueous solutions by secondary feldspars; (iii) the buffering of silica contents by mineral equilibria; and (iv) the progressive evolution from oxygenated (low-Fe) infiltration waters to reduced (high-Fe) deeply circulating hydrothermal fluids.

In the specific Ischia case here, application of reaction path modelling provides a number of significant new information on the hydrothermal system, including (i) that leaching of groundmass secondary minerals (e.g., clay minerals and zeolites) sources a significant fraction of chemicals transported by hydrothermal fluids. This significant role played by dissolving secondary minerals is likely a common aspect of hydrothermal processes, often overlooked in previous studies; (ii) that composition (salinity) of infiltrating waters has an impact on the pathways of hydrothermal reactions (for instance, delaying formation of secondary feldspars at high salinity); (iii) and that the chemical compositions of surface manifestations preserve memory of a range of hydrothermal reaction environments. In particular, the $\mathrm{Na}-\mathrm{K}-\mathrm{Mg}$ compositions of Ischia's thermal water samples (at least of the poorest in $\mathrm{Mg}$ ) are best matched by high-temperature $\left(180-260^{\circ} \mathrm{C}\right)$ model runs, indicating they reflect quenched equilibria at deep-reservoir conditions. Iron, $\mathrm{SiO}_{2}$ and, to a lesser extent, $\mathrm{SO}_{4}$ contents of natural samples are instead better reproduced by low-temperature $\left(95^{\circ} \mathrm{C}\right)$ runs. These species therefore reflect conditions of water-rock interaction in the shallow Ischia's hydrothermal environment.

In light of the results obtained here, reaction path modelling should become an essential technique to investigate hydrothermal systems. 


\section{ACKNOWLEDGEMENTS}

The INGV-Palermo staff is acknowledged for support. We thank Dr. R. Brown for providing a representative rock sample of MEGT. The precious assistance of Dr. Andrea Cavallo (INGV, Rome, Italy) for providing valuable technical support during microprobe analyses, is warmly acknowledged. Insightful comments from the Associate Editor (Wolfgang Bach) and 2 anonymous Reviewers contributed to improve the quality of the manuscript.

\section{APPENDIX A. SUPPLEMENTARY DATA}

Supplementary data associated with this article can be found, in the online version, at http://dx.doi.org/10.1016/ j.gca.2012.11.039.

\section{REFERENCES}

Aiuppa A., Federico C., Allard P., Gurrieri S. and Valenza M. (2005) Trace metal modelling of groundwater-gas-rock interactions in a volcanic aquifer: Mount Vesuvius (Southern Italy). Chem. Geol. 216, 289-311.

Aiuppa A., Avino R., Brusca L., Caliro S., Chiodini G., D’Alessandro W., Favara R., Federico C., Ginevra W., Inguaggiato S., Longo M., Pecoraino G. and Valenza M. (2006) Mineral control of arsenic content in thermal waters from volcanohosted hydrothermal systems: insights from island of Ischia and Phlegrean Field (Campanian Volcanic Province, Italy). Chem. Geol. 229, 313-330.

Ambrosio M., Doveri M., Fagioli M. T., Marini L., Principe C. and Raco B. (2010) Water-rock interaction in the magmatichydrothermal system of Nisyros Island (Greece). J. Volcanol. Geotherm. Res. 192, 57-68.

Barra D., Cinque A., Italiano A. and Scorziello R. (1992) Il Pleistocene superiore marino di Ischia: paleoecologia e rapporti con l'evoluzione tettonica recente. Stud. Geol. Camerti 1, 231243.

Berner E. K. and Berner R. A. (1996) Global Environment: Water, Air, and Geochemical Cycles. Prentice Hall, Upper Saddle River, 376p.

Brocchini F., Principe C., Castradori D., Laurenzi M. A. and Goria L. (2001) Quaternary evolution of the southern sector of the Campanian Plain and early Somma-Vesuvius activity: insights from the Trecase well. Mineral. Petrol. 73, 67-91.

Brown R. J., Orsi G. and de Vita S. (2008) New insights into Late Pleistocene explosive volcanic activity and caldera formation on Ischia (southern Italy). B. Volcanol. 70, 583-603.

Browne P. R. L. (1978) Hydrothermal alteration in active geothermal fields. Annu. Rev. Earth Planet. Sci. 6, 229-250.

Browne P. R. L. and Ellis A. (1970) The Ohaki-Broadlands hydrothermal area, New Zealand: Mineralogy and related geochemistry. Am. J. Sci. 269, 97-131.

Calcaterra D., Cappelletti P., Langella A., Colella A. and de Gennaro M. (2004) The ornamental stones of Caserta province: the Campanian Ignimbrite in the medieval architecture of Casertavecchia. J. Cult. Herit. 5, 137-148.

Caliro S., Panichi C. and Stanzione D. (1999) Variation in the total dissolved carbon isotope composition of thermal waters of the Island of Ischia (Italy) and its implications for volcanic surveillance. J. Volcanol. Geotherm. Res. 90, 219-240.

Caprarelli G., Tsutsumi M. and Turi B. (1997) Chemical and isotopic signatures of the basement rocks from the Campi Flegrei geothermal field, Naples, southern Italy: inferences about the origin and evolution of its hydrothermal fluids. $J$. Volcanol. Geotherm. Res. 76, 63-82.

Carapezza M., Hauser S., Parello F., Scelsi E., Valenza M., Favara R. and Guerrieri S. (1988) Preliminary studies on the geothermal fluids of the island of Ischia: gas geochemistry. Rend. Soc. Ital. Mineral. Petrol. 43, 967-974.

Carbonin S., Dal Negro A., Molin G. M., Munno R., Rossi G., Lirer L. and Piccirillo E. M. (1984) Crystal chemistry of Ca-rich pyroxenes from undersaturated to oversaturated trachytic rocks, and their relationships with pyroxenes from basalts. Lithos 17, 191-202.

Celico P., Stanzione D., Esposito L., Formica F., Piscopo V. and De Rosa B. (1999) La complessità idrogeologica di un'area vulcanica attiva: l'Isola di Ischia (Napoli-Campania). Boll. Soc. Geol. Ital. 118, 485-504.

Chen Y. and Brantley S. L. (1998) Diopside and anthophyllite dissolution at $25^{\circ} \mathrm{C}$ and $90{ }^{\circ} \mathrm{C}$ and acid pH. Chem. Geol. 147, 233-248.

Chiodini G. and Marini L. (1988) Hydrothermal gas equilibria: The $\mathrm{H}_{2} \mathrm{O}-\mathrm{H}_{2}-\mathrm{CO}_{2}-\mathrm{CO}-\mathrm{CH}_{4}$ system. Geochim. Cosmochim. Acta 62, 2673-2687.

Chiodini G., Avino R., Brombach T., Caliro S., Cardellini C., De Vita S., Frondini F., Granieri D., Marotta E. and Ventura G. (2004) Fumarolic and diffuse soil degassing west of Mount Epomeo, Ischia, Italy. J. Volcanol. Geotherm. Res. 133, 291309.

Civetta L., Gallo G. and Orsi G. (1991) Sr and Nd isotope and trace element constraints on the chemical evolution of the magmatic system of Ischia Italy in the last $55 \mathrm{ka}$. J. Volcanol. Geotherm. Res. 46, 213-230.

Colella A., Calcaterra D., Cappelletti P., Langella A., Papa L. and de Gennaro M. (2009) I tufi zeolitizzati nell'architettura della Campania. In La diagnostica per il restauro del patrimonio culturale (ed. Cuzzolin). Atti del Convegno Diacomast 2008, pp. 327-341.

Creasey S. C. (1966) Hydrothermal alteration. In Geology of the porphyry copper deposits (ed. Titley S. R. and Hicks C. L.). Arizona Univ. Press. pp. 51-74.

D'Antonio M. and Kristensen M. B. (2005) Hydrothermal alteration of oceanic crust in the West Philippine Sea Basin (Ocean Drilling Program Leg 195, Site 1201): inferences from a mineral chemistry investigation. Mineral. Petrol. 83, 87-112.

D’Antonio M., Tonarini S., Arienzo I., Civetta L. and Di Renzo V. (2007) Components and processes in the magma genesis of the Phlegrean Volcanic District, southern Italy. In Cenozoic volcanism in the mediterranean area (eds. L. Beccaluva, G. Bianchini and M. Wilson). Geol. Soc. Am. Sp. Pap. 418. pp. 203220.

De Gennaro M., Ferreri M., Ghiara M. R. and Stanzione D. (1984) Geochemistry of thermal waters on the island of Ischia (Campania, Italy). Geothermics 13, 361-374.

De Vivo B., Belkin H. E., Barbieri M., Chelini W., Lattanzi P., Lima A. and Tolomeo L. (1989) The Campi Flegrei, Italy, geothermal system: a fluid inclusion study of the Mofete and S. Vito Fields. J. Volcanol. Geotherm. Res. 36, 303-326.

Deer W. A., Howie R. A. and Zussman J. (1992) An Introduction to the Rock-forming Minerals, 2nd ed. Longman Scientific \& Technical, Harlow, 696 p.

Deer W. A., Howie R. A. and Zussman J. (1997) Rock-forming Minerals. 1B: Disilicates and Ring Silicates, 2nd ed. Geological Society, London, 764p.

Di Napoli R., Aiuppa A., Bellomo S., Brusca L., D’Alessandro W., Gagliano Candela E., Longo M., Pecoraino G. and Valenza M. (2009) A model for Ischia hydrothermal system: evidences from the chemistry of thermal groundwaters. J. Volcanol. Geotherm. Res. 186, 133-159. 
Di Napoli R., Martorana R., Orsi G., Aiuppa A., Camarda M., De Gregorio S., Gagliano Candela E., Luzio D., Messina N., Pecoraino G., Bitetto M., de Vita S. and Valenza M. (2011) The structure of a hydrothermal system from an integrated geochemical, geophysical, and geological approach: the Ischia Island case study. Geochem. Geophys. Geosyst. 12, 1-25.

Drever J. I. (1997) The Geochemistry of Natural Waters: Surface and Groundwater Environments. Prentice Hall, New Jersey, $437 \mathrm{p}$.

Ellis A. J. (1971) Magnesium ion concentration in the presence of magnesium chlorite, calcite, carbon dioxide, quartz. Am. J. Sci. 271, 481-489.

Ellis A. J. and Wilson S. H. (1960) The geochemistry of alkali metal ions in the Wairakei hydrothermal system. NZ J. Geol. Geophys. 3, 593-617.

Ellis A. J. and Mahon W. A. J. (1964) Natural hydrothermal systems and experimental hot-water/rock interactions. Geochim. Cosmochim. Acta 28, 1323-1357.

Federico C., Pizzino L., Cinti D., De Gregorio S., Favara R., Galli G., Giudice G., Gurrieri S., Quattrocchi F. and Voltattorni N. (2008) Inverse and forward modelling of groundwater circulation in a seismically active area (Monferrato, Piedmont, NW Italy): Insights into stress-induced variations in water chemistry. Chem. Geol. 248, 14-39.

Fowler S. J., Spera F. J., Bohrson W. A., Belkin H. E. and De Vivo B. (2007) Phase equilibria constraints on the chemical and physical evolution of the campanian ignimbrite. J. Petrol. 48, 459-493.

Fulignati P., Malfitano G. and Sbrana A. (1997) The Pantelleria caldera geothermal system: data from the hydrothermal minerals. J. Volcanol. Geotherm. Res. 75, 251-270.

Fulignati P., Gioncada A. and Sbrana A. (1998) Geologic model of the magmatic-hydrothermal system of Vulcano (Aeolian Islands, Italy). Mineral. Petrol. 62, 195-222.

Gambardella B., Marini L. and Baneschi I. (2005) Dissolved potassium in the shallow groundwaters circulating in the volcanic rocks of central-southern Italy. Appl. Geochem. 20, 875-897.

Gianelli G. and Grassi S. (2001) Water-rock interaction in the active geothermal system of Pantelleria, Italy. Chem. Geol. 181, $113-130$.

Giggenbach W. F. (1984) Mass transfer in hydrothermal alteration systems - a conceptual approach. Geochim. Cosmochim. Acta 48, 2693-2711.

Giggenbach W. F. (1988) Geothermal solute equilibria. Derivation of $\mathrm{Na}-\mathrm{K}-\mathrm{Mg}-\mathrm{Ca}$ geoindicators. Geochim. Cosmochim. Acta 52, 2749-2765.

Gislason S. R. and Eugster H. P. (1987) Meteoric water-basalt interactions. I: A laboratory study. Geochim. Cosmochim. Acta 51, 2827-2840.

Gysi A. P. and Stefánsson A. (2011) $\mathrm{CO}_{2}$-water-basalt interaction. Numerical simulation of low temperature $\mathrm{CO}_{2}$ sequestration into basalts. Geochim. Cosmochim. Acta 75, 4728-4751.

Gysi A. P. and Stefánsson A. (2012) Experiments and geochemical modeling of $\mathrm{CO}_{2}$ sequestration during hydrothermal basalt alteration. Chem. Geol. 306-307, 10-28.

Hedenquist J. W. and Lowenstern J. B. (1994) The role of magmas in the formation of hydrothermal ore deposits. Nature 370, 519-527.

Helgeson H. C. (1968) Evaluation of irreversible reactions in geochemical processes involving minerals and aqueous solutions: I. Thermodynamic relations. Geochim. Cosmochim. Acta 32, 853-877.

Helgeson H. C. (1979) Mass transfer among minerals and hydrothermal solutions. In Geochemistry of Hydrothermal Ore
Deposits (ed. H. L. Barnes). John Wiley and Sons, New York, pp. 568-610.

Helgeson H. C., Garrels R. M. and Mackenzie F. T. (1969) Evaluation of irreversible reactions in geochemical processes involving minerals aqueous solutions: II. Applications. Geochim. Cosmochim. Acta 33, 455-481.

Helgeson H. C., Brown T. H., Nigrini A. and Jones T. A. (1970) Calculation of mass transfer in geochemical processes involving minerals and aqueous solutions. Geochim. Cosmochim. Acta 34, 569-592.

Hurwitz S., Evans W. C., Lowenstern J. B., Bergfeld D., Werner C., Heasler H., and Jaworowski C. (2007) Extensive hydrothermal rock alteration in a low $\mathrm{pH}$, steam-heated environment: Hot Springs Basin, Yellowstone National Park. In Proceedings of the 12th International Symposium on Water-Rock, Interaction. pp. 81-85.

Krauskopf K. B. and Bird D. K. (1995) Introduction to Geochemistry. McGraw-Hill, New York, 647p.

Inguaggiato S., Pecoraino G. and D'Amore F. (2000) Chemical and isotopic characterization of fluid manifestations of Ischia Island. J. Volcanol. Geotherm. Res. 99, 151-178.

Ippolito F. (1942) Su alcuni pozzi profondi del napoletano. Boll. Soc. Nat. Napoli 53, 134-140.

Langmuir D. (1997) Aqueous Environmental Geochemistry. Prentice-Hall, Upper Saddle River, New Jersey, 600 p.

Lelli M., Cioni R. and Marini L. (2008) The double solid reactant method: II. An application to the shallow groundwaters of the Porto Plain, Vulcano Island (Italy). Environ. Geol. 56, 139-158. http://dx.doi.org/10.1007/s00254-007-1147-2.

Lonker S. W., Franzson H. and Kristmannsdóttir H. (1993) Mineral-fluid interactions in the Reykjanes and Svartsengi geothermal systems, Iceland. Am. J. Sci. 293, 605-670.

Lowell J. D. and Guilbert J. M. (1970) Lateral and vertical alteration-mineralization zoning in porphyry ore deposits. Econ. Geol. 65, 373-408.

Markússon S. H. and Stefánsson A. (2011) Geothermal surface alteration of basalts, Krýsuvík Iceland-Alteration mineralogy, water chemistry and the effects of acid supply on the alteration process. J. Volcanol. Geotherm. Res. 206, 46-59.

McDowell S. D. and Elders W. A. (1980) Authigenic layer silicated minerals in borehole Elmore I, Salton Sea Geothermal field, California, USA. Contrib. Mineral. Petrol. 74, 293-310.

Meyer C. and Hemley J. J. (1967) Wallrock alteration. In Geochemistry of Hydrothermal ore Deposits (ed. H. L. Barnes). Rinehart and Wilson Publ., pp. 166-235.

Morell I., Pulido-Bosch A., Daniele L. and Virgilio Cruz J. (2008) Chemical and isotopic assessment in volcanic thermal waters: cases of Ischia (Italy) and São Miguel (Azores, Portugal). Hydrol. Process. 22, 4386-4399.

Moretti R., Arienzo I., Orsi G., Civetta L. and D'Antonio M. (2011) The deep plumbing system of the Ischia island: a physico-chemical window on the fluid-saturated and $\mathrm{CO}_{2}-$ sustained Neapolitan volcanism (Southern Italy). Mineral. Mag. 75, 1499.

Muffler L. J. and White D. E. (1969) Active metamorphism of Upper Cenozoic sediments in the Salton Sea geothermal field and the Salton Trough, Southeastern California. Bull. Geol. Soc. Am. 80, 157-180.

Naboko S. I. (1970) Facies of hydrothermally altered rocks of Kamchatka-Kurile volcanic arc. Pac. Geol. 2, 23-27.

Orsi G., Gallo G. and Zanchi A. (1991) Simple-shearing block resurgence in caldera depression. A model from Pantelleria and Ischia. J. Volcanol. Geotherm. Res. 47, 1-11.

Orsi G., Piochi M., Campajola L., D’Onofrio A., Gialanella L. and Terrasi F. (1996) ${ }^{14} \mathrm{C}$ geochronological constraints for the 
volcanic history of the island of Ischia (Italy) over the last 5000 years. J. Volcanol. Geotherm. Res. 71, 249-257.

Orsi G., de Vita S., Di Vito M., Isaia R., Nave R. and Heiken G. (2003) Facing volcanic and related hazards in the Neapolitan area. In Earth Sciences in Cities (eds. G. Heiken, R. Fakundiny and J. Sutter). American Geophysical Union (Special Publication), Washington. pp. 121-170.

Palandri J. L. and Kharaka Y. K. (2004) A compilation of rate parameters of water-mineral interaction kinetics for application to geochemical modeling. US Geol. Surv. Open File Rep. 2004 1068.

Panichi C., Bolognesi L., Ghiara M. R., Noto P. and Stanzione D. (1992) Geothermal assessment of the island of Ischia (southern Italy) from isotopic and chemical composition of the delivered fluids. J. Volcanol. Geotherm. Res. 49, 329-348.

Penta F. (1949) Temperature nel sottosuolo della regione Flegrea. Ann. Geophys. 2, 327-346.

Penta F. (1954) Ricerche e studi sui fenomeni esalativo-idrotermali e il problema delle "forze endogene". Ann. Geophys. 8, 317-408.

Penta F. and Conforto B. (1951a) Sulle misure di temperatura del sottosuolo nei fori trivellati in presenza di acqua e sui relativi rilievi freatimetrici in regioni idrotermali. Ann. Geophys. 4, 4193.

Penta F. and Conforto B. (1951b) Risultati di sondaggi e di ricerche geominerarie nell'Isola di Ischia dal 1939 al 1943, nel campo del vapore, delle acque termali e delle "forze endogene" in generale. Ann. Geophys. 4, 159-191.

Que M. and Allen A. R. (1996) Sericitization of Plagioclase in the Rosses Granite Complex, Co. Donegal, Ireland. Mineral. Mag. 60, 927-936.

Ragnarsdòttir K. V. (1993) Dissolution kinetics of heulandite at pH 2-12 and $25^{\circ}$ C. Geochim. Cosmochim. Acta 57, 2439-2449.

Reed M. H. (1982) Calculation of multicomponent chemical equilibria and reaction processes in systems involving minerals, gases and an aqueous phase. Geochim. Cosmochim. Acta 46, 513-528.

Rock N. M. S. (1990) The International Mineralogical Association (IMA/CNMMN) pyroxene nomenclature scheme: computerization and its consequences. Mineral. Petrol. 43, 99-119.

Rose A. N. (1970) Zonal relations of wall rock alteration and sulfide distribution of porphyry copper deposits. Econ. Geol. 65, 920-936.

Sbrana A., Fulignati P., Marianelli P., Boyce A. J. and Cecchetti A. (2009) Exhumation of an active magmatic hydrothermal system in a resurgent caldera environment. The example of Ischia Island (Italy). J. Geol. Soc. London 166, 1061-1073.

Sbrana A., Fulignati P. and Marianelli P. (2010) Development and fast exhumation of a geothermal system in a resurgent caldera environment. The example of Ischia Island (Italy). In Proceedings World Geothermal Congress. pp 1-5.

Stefánsson A. (2010) Low-temperature alteration of basalts - the effects of temperature, acids and extent of reaction on mineralization and water chemistry. Jokull 60, 165-184.

Stefánsson A., Arnórsson S., Gunnarsson I., Kaasalainen H. and Gunnlaugsson E. (2011) The geochemistry and sequestration of $\mathrm{H}_{2} \mathrm{~S}$ into the geothermal system at Hellisheidi, Iceland. $J$. Volcanol. Geotherm. Res. 202, 179-188.

Steinmann P., Lichtner P. C. and Shotyk W. (1994) Reaction path approach to mineral weathering reactions. Clays Clay Miner. 42, 197-206.

Stormer, Jr., J. C. (1983) The effects of recalculation on estimates of temperature and oxygen fugacity from analyses of multicomponent iron-titanium oxides. Am. Mineral. 68, 586-594.

Stumm W. and Morgan J. J. (1996) Aquatic Chemistry, Chemical Equilibria and Rates in Natural Waters, 3rd ed. John Wiley \& Sons, Inc., New York, 1022p.

Symonds R. B., Gerlac T. M. and Reed M. H. (2001) Magmatic gas scrubbing: implications for volcano monitoring. J. Volcanol. Geotherm. Res. 108, 303-341.

Tedesco D. (1996) Chemical and isotopic investigations of fumarolic gases from Ischia island southern Italy: evidences of magmatic and crustal contribution. J. Volcanol. Geotherm. Res. 74, 233-242.

Tempel R. N., Sturmer D. M. and Schilling J. (2011) Geochemical modeling of the near-surface hydrothermal system beneath the southern moat of Long Valley Caldera, California. Geothermics 40, 91-101.

Vezzoli L. (1988) Island of Ischia. In Quaderni de La Ricerca Scientifica, vol. 114. C.N.R., Rome. 133p.

White D. E. (1957) Magmatic, connate, and metamorphic waters. Geol. Soc. Am. Bull. 69, 1659-1682.

Wolery T. J. and Daveler S. A. (1992) EQ6, a computer program for reaction path modeling of aqueous geochemical systems: theoretical manual, user's guide and related documentation (version 7.0). Report UCRl-MA-110662 PT IV. Lawrence Livermore National Laboratory, Livermore, California.

Yavuz F. (2001) PYROX: a computer program for the IMA pyroxene classification and calculation scheme. Comput. Geosci. 27, 97-107.

Yavuz F. (2003) Evaluating micas in petrologic and metallogenic aspect: I-definitions and structure of the computer program MICA+. Comput. Geosci. 29, 1203-1213.

Associate editor: Wolfgang Bach 